\title{
Anomalous 1992 spring and summer right whale (Eubalaena glacialis) distributions in the Gulf of Maine
}

\author{
ROBERT D. KENNEY \\ University of Rhode Island, Graduate School of Oceanography, Bay Campus Box 41, Narragansett, RI 02882-1197, USA \\ Contacte-mail: rkenney@gso.uri.edu
}

\begin{abstract}
No right whales (Eubalaena glacialis) were sighted during aerial surveys in May-July 1992 in the Great South Channel region of the southwestern Gulf of Maine. This was the first year that spring surveys failed to detect right whales in this region. During the late spring/early summer season when right whales would normally be expected in the Great South Channel, a few were sighted in the central Gulf of Maine, none were found in their usual late summer/early autumn feeding areas near Nova Scotia and a few were seen in Massachusetts Bay. The absence of right whales in the Great South Channel in 1992 can be attributed to a shift in the regional zooplankton community. The usual spring zooplankton of the region is strongly dominated by the calanoid copepod Calanus finmarchicus, vertically and horizontally aggregated into dense patches which are the preferred foraging areas of right whales. The 1992 zooplankton was dominated by pteropods, distributed evenly throughout the water column. It is possible, although unlikely, that pteropods are unacceptable prey for right whales. A more likely explanation is that their local densities within small-scale patches were below the energetic threshold required for successful right whale feeding. The shift in zooplankton dominance in 1992 is likely related to significantly reduced water temperatures and a delay in the development of the usual hydrographic structure of the region. The 1992 temperature and hydrographic anomalies, in turn, can be attributed principally to an unusually large influx of colder and fresher Scotian Shelf Water, and may have been enhanced by widespread cooling of the Northern Hemisphere caused by sulphuric acid haze in the atmosphere from the June 1991 eruption of Pinatubo volcano in the Philippines.
\end{abstract}

KEYWORDS: NORTHERN RIGHT WHALE; ATLANTIC OCEAN; DISTRIBUTION; CLIMATE CHANGE; ECOSYSTEM; OCEANOGRAPHY; FEEDING GROUNDS; PREY; PATCHES

\section{INTRODUCTION}

The North Atlantic right whale (Eubalaena glacialis) is the most endangered large whale species in the world (Braham and Rice, 1984; IWC, 1986; NMFS, 1991), with a western North Atlantic population of around 300 animals (e.g. see IWC, 2001a). Right whales in the western North Atlantic have been studied intensively since the late 1970s, and a relatively clear picture of their patterns of distribution in space and time emerged by the early 1990s (Kraus, 1985; Winn et al., 1986; Gaskin, 1987; 1991; Kraus et al., 1988; Kraus and Kenney, 1991; IWC, 2001b). Four important right whale feeding habitats are found in the continental shelf waters off the northeastern United States and southeastern Canada (Fig. 1). Right whales first arrive in northeastern waters in late winter in the relative shallows of Cape Cod Bay, with peak occurrence there in April (Hamilton and Mayo, 1990). Cape Cod Bay is typically occupied each year by approximately 25-50 individuals (Hamilton and Mayo, 1990; Kraus and Kenney, 1991). Right whales are then found in late spring and early summer in the Great South Channel (GSC) region east of Cape Cod, which is the primary spring feeding habitat for the western North Atlantic population (CETAP, 1982; Winn et al., 1986; Kraus and Kenney, 1991; Kenney et al., 1995). Right whales are found during the rest of the summer and into the autumn in two habitats in Canadian waters (Gaskin, 1987; 1991; Kraus et al., 1988; Murison and Gaskin, 1989). A smaller portion of the population, including nearly all of the mother/calf pairs, is found in the lower Bay of Fundy to the east of Grand Manan Island, an area known as the Grand Manan Basin. The majority of the adult population occurs in continental shelf waters off southern Nova Scotia, centred in the Roseway Basin just north of Browns Bank.

The University of Rhode Island (URI) collected a near-continuous time-series of springtime survey and sightings data for the GSC region from 1979 through 1991 (excluding 1990). These data suggest that at times the entire (or almost entire) population occupies the region (Kenney et al., 1995). Right whales typically are found in the GSC area from April to June, with a peak in May (Winn et al., 1986; Kraus and Kenney, 1991; Kenney et al., 1995). Departure from the area (apparently differing between years) occurs between late May and early July (Kenney et al., 1995). Right whale sightings in the GSC are primarily in the central portions of the region, mostly in waters deeper than $100 \mathrm{~m}$. They are found in aggregations which coincide with the dense patches of the zooplankton upon which they feed (CETAP, 1982; Scott et al., 1985; Kenney et al., 1986a; Wishner et al., 1988; 1995; Macaulay et al., 1995; Beardsley et al., 1996). These aggregations occur north of a tidal-mixing front (roughly coincident with the $100 \mathrm{~m}$ isobath) which divides deeper, stratified waters with warmer surface temperatures from shallow, totally-mixed waters with colder surface temperatures (CETAP, 1982; Scott et al., 1985; Wishner et al., 1988; 1995; Brown and Winn, 1989; Kenney et al., 1995; Macaulay et al., 1995). The stratified waters are north of the front and the tidally-mixed waters south of it (Wishner et al., 1988; Brown and Winn, 1989; Chen et al., 1995b).

The 1992 spring aerial surveys began in May. The results of the first surveys immediately suggested that the distribution of right whales in the GSC was atypical; none were sighted during two complete GSC surveys. The sampling design was then altered to expand the number and geographic range of the aerial surveys. The objectives of the expanded survey programme were to:

(1) conduct aerial surveys of the GSC area, and as much of the rest of the Gulf of Maine as possible - the goals were to survey the GSC to confirm/refute the apparent absence of right whales there, and to locate concentrations of right whales outside of the GSC, particularly in their normal late summer/autumn habitats in the Bay of Fundy and shelf waters south of Nova Scotia; 
(2) explore the possible oceanographic mechanisms which might be responsible for atypical right whale distributions by using available information and, in particular, consultation with other researchers collecting physical and biological oceanographic data in the Gulf of Maine.

\section{METHODS}

\section{Aerial surveys}

The standard GSC aerial surveys conducted by URI followed a sampling design, protocol and survey block which remained constant since 1984 (Fig. 1), using methods standardised during the Cetacean and Turtle Assessment Program (CETAP, 1982; Scott and Gilbert, 1982). All surveys were flown in a twin-engine Cessna 337-G Skymaster, which was equipped with a Barnes PRT-5 infra-red radiometer to measure sea surface temperature (recorded by a computer data-logger with time and position at $15 \mathrm{sec}$ intervals). All right whale sightings were circled to obtain accurate counts, observe behaviour and take photographs for individual identification (see Kraus et al., 1986 for details of photo-identification methods). Complete details of aerial survey methods can be found in Kenney et al. (1995).

Additional aerial surveys were conducted in 1992 in the Gulf of Maine and adjacent waters, with two different objectives:
(1) to search the normal late summer/autumn right whale habitats in Nova Scotian waters to see if right whales had arrived there much earlier than in previous years; and

(2) to search as much of the Gulf of Maine as feasible to locate right whale aggregations.

The survey lines were initially designed based on right whale sightings collected during the CETAP surveys, which covered the continental shelf waters from Cape Hatteras, North Carolina to Nova Scotia nearly completely. As the surveys progressed, 1992 right whale sightings made by our earlier surveys or contributed from other sources were factored into survey designs.

\section{Other sightings data}

Additional 1992 right whale sightings were obtained from the sources listed below:

(1) The National Marine Fisheries Service (NMFS) conducted several sampling programmes over the year, and right whales were sighted from three: (1) oceanographic and fisheries research cruises aboard NMFS ships; (2) a harbour porpoise (Phocoena phocoena) cruise aboard R/V Abel J; and (3) an aerial harbour porpoise survey.

(2) The Center for Coastal Studies (CCS) conducted research cruises aboard R/V Halos in Cape Cod Bay from February to April, and also collected data from observers aboard commercial whalewatching vessels from April to October.

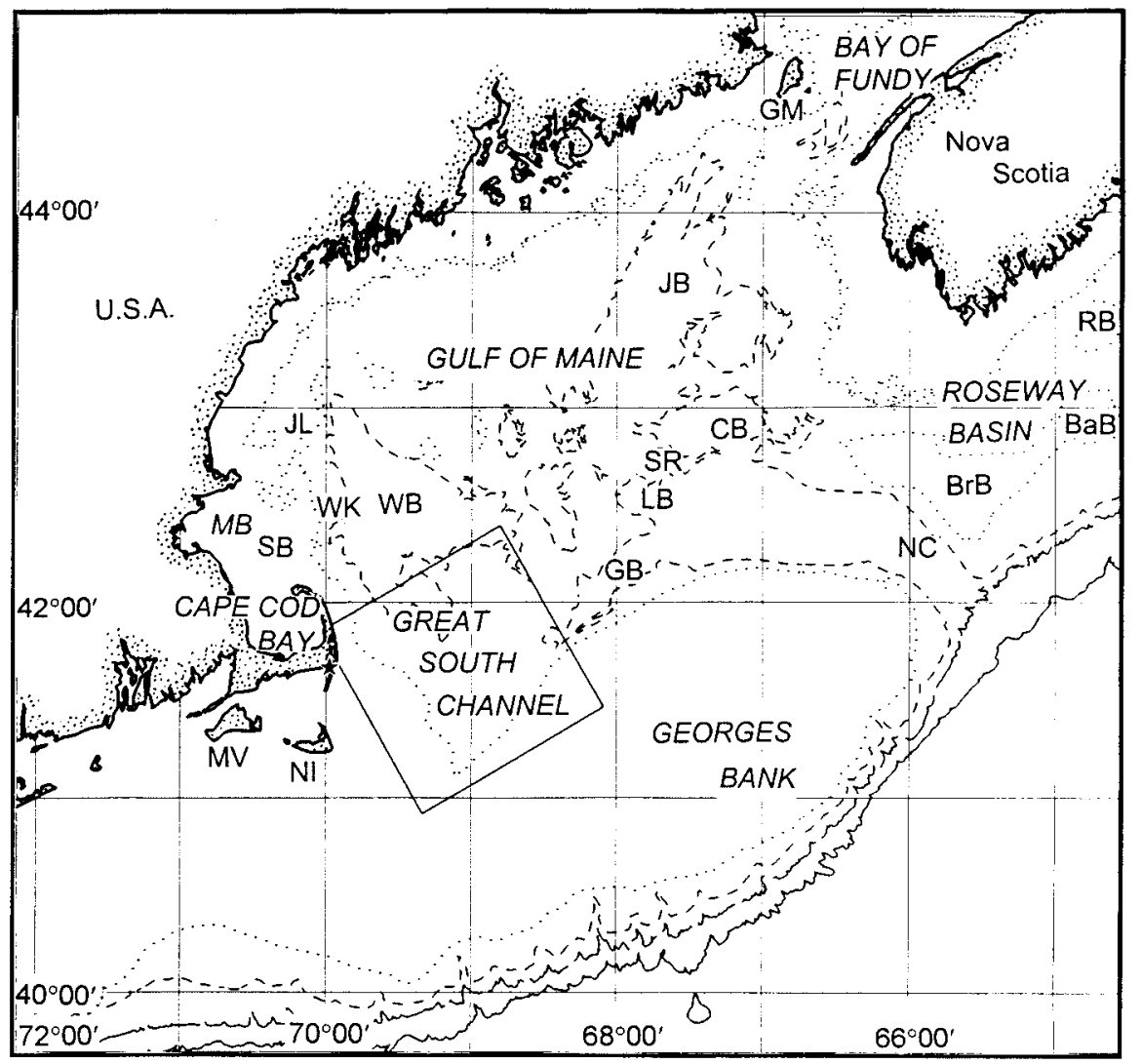

Fig. 1. The continental shelf region off the northeastern United States and southeastern Canada, showing the four important right whale feeding habitats and other areas referred to in the text. The block east of Cape Cod is the Great South Channel aerial survey block, and the star at the southeast corner of Cape Cod shows the location of the Chatham weather station. The isobaths shown are at 100, 200, 1,000 and 2,000m. Key to abbreviations: $\mathrm{BaB}=$ Baccaro Bank; $\mathrm{BrB}=$ Browns Bank; $\mathrm{CB}=$ Crowell Basin; $\mathrm{GB}=$ Georges Basin; GM = Grand Manan Island; JB = Jordan Basin; JL = Jeffreys Ledge; LB = Lindenkohl Basin; MB = Massachusetts Bay; MV = Martha's Vineyard; NC = Northeast Channel; NI = Nantucket Island; RB = Roseway Bank; SB = Stellwagen Bank; SR = Sewall Ridge; WB = Wilkinson Basin; WK = Wildcat Knoll. La Have Bank, Emerald Bank, and Sable Island Bank are located on the shelf south of Nova Scotia east of the area mapped here. 
(3) The New England Aquarium (NEA) conducted vessel surveys aboard R/V Nereid in the lower Bay of Fundy from late July to early October.

(4) East Coast Ecosystems (ECE) conducted two days of vessel surveys in September in the Roseway Basin area in conjunction with NEA and Brier Island Ocean Studies (BIOS) aboard M/V Cetacean Quest, the BIOS whalewatching vessel.

(5) The Canadian Department of Fisheries and Oceans (DFO) collected sightings recorded by fisheries observers aboard commercial fishing vessels.

Data from all these sources were included into a common database which is maintained at URI as part of a cooperative research project involving all of the above organisations which has been underway since 1986. Another component of the cooperative effort is the maintenance of the photo-identification catalogue (Crone and Kraus, 1990) at NEA and the joint maintenance of the catalogue database by NEA and URI. The catalogue includes photographs submitted to NEA by a wide variety of sources, and any 1992 catalogue records from these other sources were also added to the sightings database.

\section{Data analysis}

All data were handled according to protocols designed for the cooperative research programme. All data processing and management have been accomplished on a series of IBM-compatible personal computer systems. Distributional analyses were performed by plotting the locations of sightings on a standard base map using CAMRIS (Computer Aided Mapping and Resource Inventory System: Ford, 1989) mapping software. All other data management, analysis, graphics and archival procedures have been accomplished using successive versions of Statistical Analysis System software (PC-SAS ver. 6.04; SAS for Windows ver. $6.11 \&$ 6.12: SAS Institute, Inc., Cary, NC).

\section{Zooplankton sampling}

Zooplankton sampling was conducted in the GSC region during a submersible research cruise aboard R/V Seward Johnson on 4-8 June conducted by Howard Winn and Karen Wishner from URI. The study was planned as an investigation of zooplankton patches in the vicinity of right whale feeding aggregations. The 4 June aerial survey was scheduled to locate right whales at the beginning of the cruise, but found none in the GSC area, therefore the sites selected for sampling were based on previous years' whale sighting locations. Sampling was conducted by two methods: paired bongo and opening/closing nets $(505 \mu \mathrm{m}$ and $333 \mu \mathrm{m}$ mesh) deployed from the support ship, and pump sampling (333 $\mu \mathrm{m}$ mesh filter) directly from the submersible. Samples were preserved and counted later using standard methods (see Wishner et al., 1995). Summary data were provided by K. Wishner (pers. comm.).

\section{RESULTS}

\section{2 aerial surveys}

The first survey was flown on 20 May, which was the first time in 13 years that a complete May survey in good weather conditions resulted in no right whale sightings. By the end of July, eight days of surveys had been completed, covering a wide area of the GSC, Gulf of Maine, Nova Scotian shelf and Bay of Fundy. In addition to the standard GSC survey area, the additional specific areas surveyed included, at least once, the perimeter of Georges Bank, the central and western Gulf of Maine, the western Nova Scotian shelf near Browns Bank and Roseway Basin, the Northeast Channel and the area east of Grand Manan Island in the lower Bay of Fundy (Table 1). Plots of the tracklines flown each day are included in Kenney (1994). Only 7-9 right whales were seen throughout all of the aerial surveys (Table 1), all in the central portion of the Gulf of Maine.

Table 1

Summary of 1992 aerial right whale surveys in the Gulf of Maine, showing the general area(s) surveyed and number of right whales sighted each day. $(\mathrm{GSC}=$ Great South Channel).

\begin{tabular}{llc}
\hline Date & Area surveyed & $\begin{array}{c}\text { Right whales } \\
\text { sighted }\end{array}$ \\
\hline 20 May & $\begin{array}{l}\text { Standard GSC survey } \\
\text { 29 May }\end{array}$ & 0 \\
& $\begin{array}{l}\text { Standard GSC survey, extended 37 km east; } \\
\text { also Cape Cod Bay, Stellwagen Bank, Jeffreys }\end{array}$ & 0 \\
& $\begin{array}{l}\text { Ledge and Wildeat Knoll in extreme western } \\
\text { Gulf of Maine }\end{array}$ & 1 \\
4 Jun. & $\begin{array}{l}\text { Central GSC; perimeter of Georges Bank } \\
\text { (western 3/4) }\end{array}$ & $4-6$ \\
17 Jun. & $\begin{array}{l}\text { Central Gulf of Maine; with transits across GSC } \\
\text { and along northwestern flank of Georges Bank }\end{array}$ & 0 \\
8 Jul. & $\begin{array}{l}\text { Lower Bay of Fundy, western Roseway Basin } \\
\text { 14 Jul. }\end{array}$ & 0 \\
30 Jul. & $\begin{array}{l}\text { Eastern Georges Bank, Northeast Channel, } \\
\text { southern and western Browns Bank }\end{array}$ & 0 \\
31 Jul. & $\begin{array}{l}\text { Zig-zag' across Gulf of Maine from Nova } \\
\text { Scotia to New England, between Georges Bank } \\
\text { and about 44 N }\end{array}$ & 2 \\
\hline
\end{tabular}

\section{Distribution of right whale sightings}

Combining the data from the aerial surveys and all other sources, there were 678 right whale sightings totalling 904 animals in 1992 in the waters off New England and Nova Scotia which comprise the main feeding areas of this population (Fig. 2). Since the number of animals sighted exceeds the estimated size of the population, it is obvious that some individual whales were observed on multiple occasions, however since not all individuals at all sightings are identified, the exact percentage of resightings is not known. In addition, vessel surveys targeted at right whale photography identify a much higher proportion of the individuals encountered than aerial surveys or other vessel surveys. There were an additional 81 winter sightings in the calving grounds off the southeastern USA which will not be considered here, and one much further north. The late winter/early spring and late summer/autumn patterns were typical of most years, but the number and distribution of sightings during the late spring and early summer were unusual.

\section{Late winter/early spring}

Right whales were first observed in Cape Cod Bay on 4 February, and sightings were made until 13 April. There were 199 sightings of 268 whales, which were distributed entirely within the eastern half of Cape Cod Bay (Fig. 2). These sightings represented only 37 different identified right whales over the entire period, with 9 different individuals present in February, 21 in March and 24 in April.

\section{Late spring/early summer}

During the study period from late May to late July, very few right whales (only 7-9 on the aerial surveys) were seen anywhere in the Gulf of Maine, and those were almost all in 
two locations: the central Gulf of Maine and Massachusetts Bay (Fig. 2). The first sighting, of a single individual, was on 4 June on the northern edge of Georges Bank. On 17 June, a single adult was sighted northwest of the 4 June sighting location. Later in the 17 June flight, at least three (possibly five) more right whales were sighted about $50 \mathrm{~km}$ further to the northwest. Three sightings were recorded: a single adult; a pair of adults with a possible third animal; and a sighting of a footprint and flukes only, which was identified as a 'possible' right whale. During the last survey on 31 July, a pair of right whales (\#1056 and \#1227) was seen and photographed in the deeper central basin north of Georges Bank and west of Browns Bank.

During the same period, three sightings, of a single right whale each, were reported by observers aboard NMFS research vessels. One was on 3 June, and the other two were on 11 July. All three sightings were in the same vicinity as our June and July sightings.

There were scattered right whale sightings in Massachusetts Bay in each month during late spring and early summer, totalling 11 sightings of 12 whales. Eight different whales were identified, with no individual seen on more than one day; two were sighted on 31 May, two were sighted on 22 June, a mother/calf pair was seen on 28 June and another mother/calf pair was sighted on 31 July. These sightings tended to be further north than the February-April sightings, outside Cape Cod Bay (Fig. 2).

DFO observers reported five sightings of six right whales between 20 April and 20 May on the outer Scotian Shelf in the vicinity of Emerald Bank and Sable Island Bank (beyond the eastern edge of the region mapped in Fig. 2). There was also one right whale sighted south of Iceland on 29 May.

\section{Late summer/autumn}

During the NEA surveys in the Bay of Fundy, right whales were first observed on 7 August, when 34 were sighted; the whales were still being seen in the Bay when the surveys ended in early October. There were 341 sightings of 475 animals, and 72 different individuals were identified (including four mother/calf pairs). The sightings were concentrated in the Grand Manan Basin between Grand Manan Island and Nova Scotia (Fig. 2).

The ECE surveys on the Scotian Shelf south of Nova Scotia on 9 and 10 September resulted in 23 sightings of 41 whales, with 17 individuals identified. The sightings were concentrated in the Roseway Basin north of Browns Bank (Fig. 2). There was also a sighting of 12 whales by a DFO observer on 21 October northeast of the September aggregation (Fig. 2). There was one additional DFO record of one right whale much further east near Emerald Bank on 3 August.

A total of 74 sightings was extracted from catalogue records in Massachusetts Bay and Cape Cod Bay during August-October, all to the north and west of the February-April concentration (Fig. 2). However, only eight identified individuals were seen. Two mother/calf pairs were sighted repeatedly, one from 10 August to 12 October and the other from 24 August to 10 October (the same pair seen

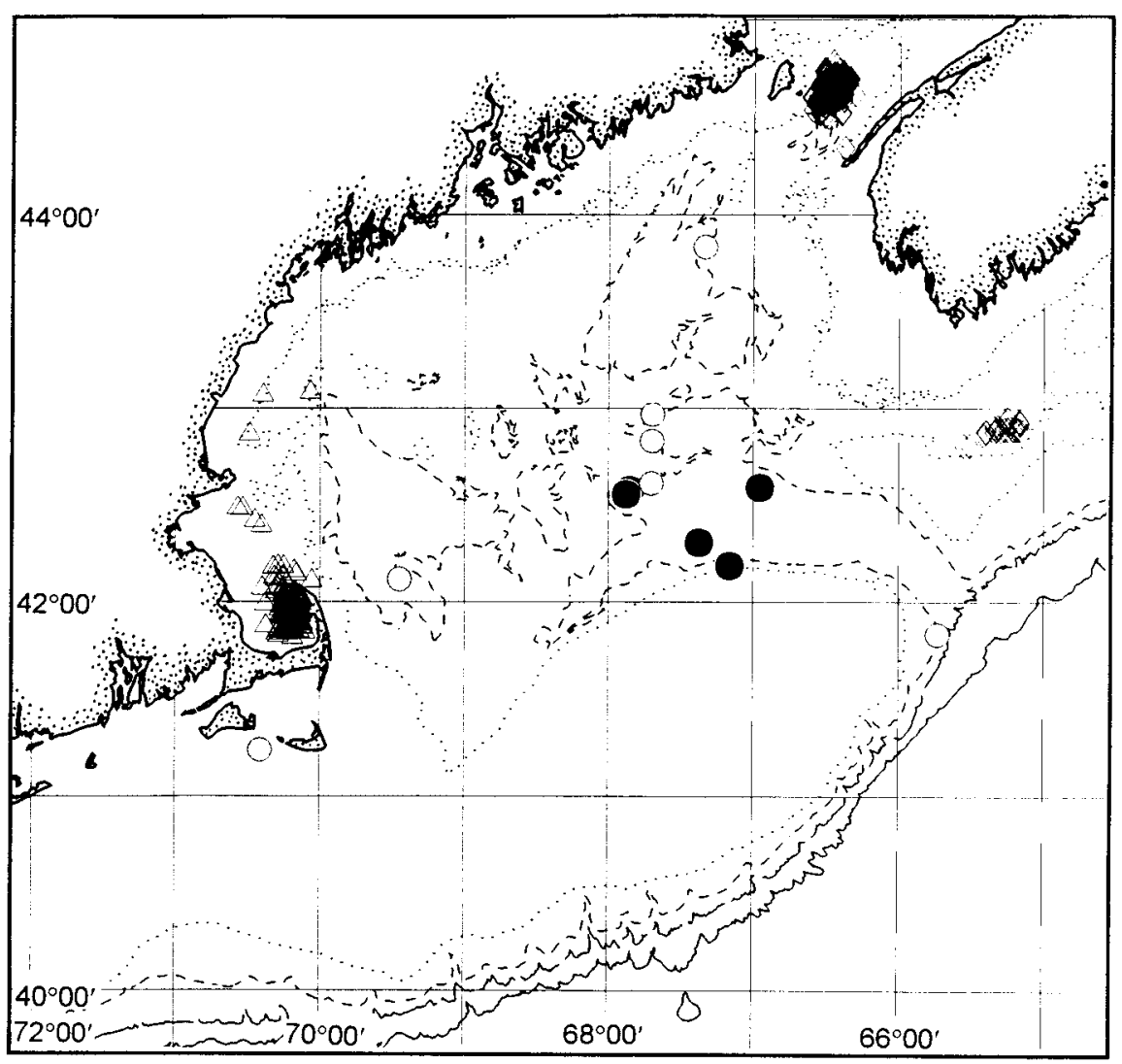

Fig. 2. All available sightings of right whales in $1992(n=672)$. The open triangles show the largely typical distribution of whales in the western Gulf of Maine from late winter through autumn $(n=294)$. The dense aggregation of sightings in Cape Cod Bay was in February-April, and the more scattered sightings on the periphery of the aggregation, to the north on Stellwagen Bank and further north on Jeffreys Ledge occurred from May to October. The open diamonds show the usual summer/autumn concentrations in the Bay of Fundy ( $n=341$; August-October) and just north of Browns Bank $(n=24 ; 9-10$ September, with the sighting which is isolated from the others on 21 October). The circles show sightings outside the usual feeding habitats and seasons. The solid circles are sightings from the URI aerial surveys in June and July ( $n=6)$. The open circles are sightings provided by other sources $(n=7)$ : three near the URI sightings in June and July, one at the eastern end of Georges Bank in late July, one in the northern Gulf of Maine in late August, one east of Cape Cod in late October and one south of Cape Cod in early December. Five additional sightings in April-May and one in August occurred on the Nova Scotian shelf 150-200km east of the boundary of this map. 
on 31 July). Two individuals were sighted from 13-18 August, and two others were seen only once on 20 or 23 October. The same two mother/calf pairs were also sighted on Jeffreys Ledge just north of Massachusetts Bay (Fig. 2), one on 8 August and 19 September, and the other on 21 August.

Three sightings were also reported by NMFS observers during the late summer and autumn (Fig. 2). One or more individuals was sighted in the north-central Gulf of Maine, on the edge of Jordan Basin, on 20 August. A single individual was sighted on 20 October on the edge of Wilkinson Basin just north of the GSC (the only sighting of the year within the GSC area). Finally, a single individual was seen on 10 December just south of the channel between Martha's Vineyard and Nantucket.

\section{Biological and physical oceanographic parameters Zooplankton}

Zooplankton species patterns in the GSC in 1992 were also atypical (K.F. Wishner, pers. comm.). In previous spring seasons, the GSC zooplankton community has been strongly dominated by copepods, and the copepod assemblage in turn dominated by the calanoid species Calanus finmarchicus, frequently to the point that samples yielded nearly monospecific collections of Calanus (CETAP, 1982; Scott et al., 1985; Kenney et al., 1986a; Sherman et al., 1987; Wishner et al., 1988; 1995; Durbin et al., 1995c). Large calanoid copepods, including Calanus finmarchicus and similar species, are the preferred prey of right whales (Matthews, 1938; Tomilin, 1957; Omura et al., 1969; Watkins and Schevill, 1976; 1979; Scott et al., 1985; Kenney et al., 1986a; Gaskin, 1987; 1991; Wishner et al., 1988; Murison and Gaskin, 1989; Mayo and Marx, 1990). In June 1992, copepods comprised only $53 \%$ of the total zooplankton abundance (on a numerical basis), and Calanus represented only $37 \%$ of the total copepod abundance (i.e. approximately $20 \%$ of the total zooplankton rather than the typical $90 \%$ or more). Other copepods, including Metridia lucens, Pseudocalanus minutus and cyclopoids, were nearly equal in abundance to Calanus. The dominant zooplankton species was the shelled pteropod Limacina retroversa. The average water column pteropod abundance in 1992 was $235,000 / \mathrm{m}^{2}$, slightly lower than the average water column abundance of Calanus in 1989-255,000/ $\mathrm{m}^{2}$ (Wishner et al., 1995).

\section{Sea surface temperatures}

The available sea surface temperature (SST) data (from the airborne radiometer) within the GSC survey block from all aerial surveys from 1985-1992 were extracted from the archived database. The data series is incomplete; no surveys were flown in 1990 and the aircraft used in 1986 was not equipped with a radiometer. There was a total of 33 surveys with SST data: four in 1985, six in 1987, nine in 1988, seven in 1989, three in 1991 and four in 1992 (Table 2). Mean SSTs for the four 1992 surveys were substantially colder than those for comparable dates in earlier years. SSTs in 1992 were also more variable than in earlier years; four of the six surveys with coefficients of variation in excess of $10 \%$ were in 1992 (Table 2).

To determine if SST patterns in 1992 were statistically different from those in earlier years, temperature data from surveys between 15 May and 15 June each year were compared. Mean values for all surveys pooled within years were calculated (Table 3 ). The mean SST in 1992 was $2.3^{\circ} \mathrm{C}$ lower than in 1985 , the second coldest year, and over $6^{\circ} \mathrm{C}$ lower than the mean for 1989, the warmest year in the period analysed. All of the yearly mean SSTs differed significantly from all others (Duncan's multiple range test, $\mathrm{a}=0.05$ ). Non-parametric statistical comparisons of the 1992 SSTs with the data from each other year also showed that surface temperatures in 1992 were significantly lower than each of the others (Wilcoxon rank sum tests, $P<0.001$ in all cases).

A second aspect of SST patterns in the GSC which has an apparent relationship to right whale distribution is the presence of a tidal mixing front (Chen et al., 1995b). The front approximately coincides with the $100 \mathrm{~m}$ isobath (see Fig. 1), although it oscillates to the north and south with the tidal cycle. This front is normally persistent through most of the spring and early summer. It is often visible as a distinct change in water colour, turbidity and surface characteristics. During aerial surveys, the radiometer readings frequently show shifts of several degrees when the aircraft crosses the line of a visible front. Surface temperatures north of the front are warmer than to the south, and right whales are most often found in those waters with warmer surface signatures, about 10-11 km north of the front (CETAP, 1982; Scott et al., 1985; Brown and Winn, 1989; Kenney et al., 1995). The front marks a boundary between two different hydrographic structures or mixing regimes. To the north are thermally-stratified waters with a warm surface layer, thermocline and colder intermediate and deep layers. To the south the water column is completely mixed by strong tidal currents over the shoal areas, reducing the temperature in the upper layer by mixing up the colder bottom waters (Wishner et al., 1988; Chen et al., 1995b). It is likely that the tidal mixing front and thermal stratification are established for short intervals early in the season (April) and remixed during storm and wind events before being permanently established later (May) for the rest of the warm season (J.J. Bisagni, University of Massachusetts-Dartmouth, pers. comm.). Similar zones between tidally-mixed and stratified water masses occur in the lower Bay of Fundy and Browns/Bacarro Bank regions, where they are also associated with right whale feeding habitats (Murison and Gaskin, 1989).

In 1992, a small number of real-time images of SST patterns for the entire northeastern US shelf region were obtained as part of the survey planning process. These images were from the AVHRR (Advanced Very High Resolution Radiometer), an infrared remote-sensing system aboard an earth-orbiting satellite, and provided by the Northeast Area Remote Sensing Center at URI. Real-time images for 29 April, 30 April and 1 May showed no sign of development of any detectable front in the GSC region. On the image for 20 May, the date of the first aerial survey, there was some suggestion of temperature differences in the GSC area, but no clear front was visible on the image and no visual evidence of a front was seen by the observers during the survey. It was not until the 14 July survey that a clearly visible frontal zone, with a $3-5^{\circ} \mathrm{C}$ temperature gradient, was seen by the aerial observers. A retrospective search of processed and archived AVHRR images revealed that the seasonal tidal mixing front in the GSC was becoming established on 20 May 1992 and was well-established within the next few days (S. Wagner, University of Massachusetts-Dartmouth, pers. comm.). A detailed hydrographic transect across the region on 27-28 May 1992 at $41^{\circ} 17^{\prime} \mathrm{N}$ (Gallager et al., 1996) showed weak stratification with a thermocline at $20 \mathrm{~m}$, as well as a frontal zone near the western end of the transect, although they suggested that the observed front was something more complex than a simple tidal mixing front. 


\section{DISCUSSION}

\section{Comparison of 1992 patterns with previous years}

The patterns of right whale distribution and abundance in 1992 were consistent with distributions from previous years at the beginning and end of the year, but atypical in late spring and early summer. Right whale occupancy in Cape Cod Bay from February-April and in the Bay of Fundy from August-October was essentially the same as in previous years (Mayo, 1982; Winn et al., 1986; Gaskin, 1987; 1991; Kraus et al., 1988; Murison and Gaskin, 1989; Hamilton and Mayo, 1990). Although only two days of surveys were conducted in the Roseway Basin area in 1992, the right whales there were present in the expected location and numbers based on previous work (Winn et al., 1986; Gaskin, 1987; 1991; Kraus et al., 1988). Given the limited effort in 1992 , it is probable that there were more whales present than the 17 animals identified, and that more would have been sighted and photo-identified if additional surveys had been possible. During 1986-1991, between 47 and 120 different animals per year $($ mean $=89)$ were identified from the Roseway Basin area (from data in the catalogue).

The major 1992 anomaly was that no right whales were sighted in the Great South Channel region between May and July, the season of usual occupancy, with only a handful of sightings in the central Gulf of Maine during that period. Except for 1990, spring survey data were available for the Great South Channel for every year between 1979 and 1992 (CETAP, 1982; Winn et al., 1985; Kenney and Winn, 1986a; 1987; Kenney et al., 1986b; 1995; Kraus and Kenney, 1991), and 1992 was the only year when few right whales were observed. Since there were no surveys in April, it is possible that right whales were present early in the season in 1992, but departed much earlier than usual. However, in 1985 right whales left the area earlier than observed in any other year, and were almost gone by the end of May (only five sighted on 30 May) and absent by mid-June. Anecdotal reports that year suggested that right whales also arrived earlier than normal in the Bay of Fundy, by the beginning of July (L.D. Murison, pers. comm.), which definitely did not occur in 1992. Unfortunately, 1992 was the last year when the aerial survey programme was funded and thus there are few data to address right whale occurrence in the GSC in 1993 and subsequent years.

The area in the central Gulf of Maine where right whales were found in 1992, in the area of Georges, Lindenkohl and Crowell Basins and Sewell Ridge, is not one where right whales have been frequently sighted in the past. Despite extensive, year-round survey coverage of the entire northeastern shelf during the CETAP study, only six right whale sightings were made in that vicinity (CETAP, 1982). In the area of the central Gulf of Maine where the 1992 sightings occurred (bounded by $42^{\circ} 00^{\prime}$ and $43^{\circ} 00^{\prime} \mathrm{N}$, and $66^{\circ} 50^{\prime}$ and $68^{\circ} 00^{\prime} \mathrm{W}$ ), there was a total of approximately $7,100 \mathrm{~km}$ of aerial and shipboard surveys in good visibility and sea conditions in 1979 and 1980 (archived CETAP effort data used in Shoop and Kenney, 1992). Those surveys resulted in sightings on 25 April 1979, 19 October 1979, 2 November 1979, 31 May 1980 (two) and 13 June 1980. The aerial surveys in 1992 covered less than $900 \mathrm{~km}$ within that same area, and the NMFS cruises may have covered another $200-300 \mathrm{~km}$ (estimated assuming two or three transits across

Table 2

Comparison of Great South Channel sea surface temperatures $\left({ }^{\circ} \mathrm{C}\right.$ ) in 1992 (in bold italics) with data collected in $1985,1987,1988,1989$ and 1991. The data are sorted in calendar order with all years mixed together for comparison of similar dates between years. All temperature data were obtained via airborne radiometry.

\begin{tabular}{|c|c|c|c|c|c|c|}
\hline Date & $n$ & Mcan & SD & Minimum & Maximum & $\mathrm{CV}$ \\
\hline 26 Apr. 1988 & 390 & 10.83 & 0.304 & 10.0 & 13.2 & 2.81 \\
\hline 26 Apr. 1989 & 1,117 & 12.62 & 0.753 & 11.1 & 15.9 & 5.97 \\
\hline 26 Apr. 1991 & 1,272 & 7.71 & 1.233 & 1.3 & 12.4 & 16.00 \\
\hline 04 May 1988 & 63 & 11.19 & 0.674 & 10.4 & 15.0 & 6.02 \\
\hline 05 May 1988 & 343 & 11.19 & 0.447 & 10.0 & 12.5 & 4.00 \\
\hline 07 May 1987 & 349 & 8.82 & 0.623 & 7.7 & 10.5 & 7.07 \\
\hline 09 May 1985 & 936 & 9.19 & 0.621 & 7.4 & 10.9 & 6.75 \\
\hline 09 May 1988 & 494 & 11.78 & 0.294 & 10.5 & 12.5 & 2.50 \\
\hline 09 May 1989 & 1,138 & 13.53 & 0.636 & 11.3 & 15.2 & 4.71 \\
\hline 09 May 1991 & 1,218 & 10.45 & 0.522 & 8.3 & 12.9 & 4.99 \\
\hline 12 May 1988 & 476 & 12.74 & 0.484 & 11.7 & 17.8 & 3.80 \\
\hline 15 May 1988 & 1,426 & 12.10 & 0.616 & 10.1 & 17.5 & 5.09 \\
\hline 20 May 1992 & 1,059 & 9.18 & 1.606 & 5.2 & 20.2 & 17.51 \\
\hline 21 May 1989 & 563 & 13.48 & 0.668 & 12.4 & 16.5 & 4.95 \\
\hline 23 May 1985 & 954 & 11.21 & 0.561 & 9.5 & 12.5 & 5.00 \\
\hline 26 May 1987 & 508 & 13.15 & 1.028 & 9.5 & 15.4 & 7.82 \\
\hline 27 May 1988 & 554 & 14.99 & 0.614 & 13.2 & 22.3 & 4.10 \\
\hline 28 May 1989 & 381 & 16.83 & 0.477 & 15.1 & 17.9 & 2.83 \\
\hline 29 May 1989 & 1,120 & 15.63 & 0.746 & 12.9 & 18.5 & 4.77 \\
\hline 29 May 1992 & 1,424 & 9.24 & 1.026 & 5.2 & 12.1 & 11.11 \\
\hline 30 May 1985 & 410 & 12.13 & 0.854 & 9.3 & 13.5 & 7.04 \\
\hline 01 Jun. 1987 & 404 & 12.70 & 0.775 & 9.0 & 15.4 & 6.10 \\
\hline 03 Jun. 1988 & 645 & 16.38 & 0.916 & 13.5 & 19.0 & 5.59 \\
\hline 04 Jun. 1992 & 704 & 9.18 & 1.733 & 5.0 & 13.2 & 18.89 \\
\hline 07 Jun. 1987 & 471 & 14.39 & 0.937 & 10.5 & 15.9 & 6.51 \\
\hline 07 Jun. 1991 & 1,117 & 11.79 & 1.686 & 7.4 & 17.7 & 14.30 \\
\hline 11 Jun. 1988 & 1,150 & 16.50 & 1.273 & 12.8 & 19.2 & 7.71 \\
\hline 19 Jun. 1987 & 52 & 15.90 & 0.614 & 14.8 & 17.4 & 3.86 \\
\hline 19 Jun. 1989 & 1,400 & 17.56 & 1.050 & 12.2 & 19.4 & 5.98 \\
\hline 21 Jun. 1985 & 1,132 & 14.95 & 1.016 & 10.3 & 18.5 & 6.79 \\
\hline 30 Jun. 1989 & 1,444 & 19.44 & 1.120 & 14.8 & 26.3 & 5.76 \\
\hline 07 Jul. 1987 & 173 & 17.47 & 1.629 & 12.2 & 20.1 & 9.32 \\
\hline 14 JuI. 1992 & 1,084 & 13.71 & 2.456 & 8.2 & 18.3 & 17.91 \\
\hline
\end{tabular}


Table 3

Yearly mean Great South Channel sea surface temperatures $\left({ }^{\circ} \mathrm{C}\right.$, from airborne radiometry), in order from warmest to coldest years, limited to surveys between 15 May and 15 Junc.

\begin{tabular}{lcccccc}
\hline Year & 1989 & 1988 & 1987 & 1991 & 1985 & 1992 \\
\hline$n$ & 2,064 & 3,775 & 1,383 & 1,117 & 1,364 & 3,187 \\
Mean SST & 15.26 & 14.59 & 13.44 & 11.79 & 11.49 & 9.20 \\
\hline
\end{tabular}

the area), yet together nine right whale sightings were made. If the CETAP observers had sighted right whales at the 1992 rate, they would have made 35 or more sightings in 1979-80.

An additional anomaly in 1992 was the occurrence of small numbers of right whales from May-October in the Cape Cod vicinity. Similar residencies, although of larger numbers of animals, were observed in 1986 and 1987 (Mayo et al., 1988; Hamilton and Mayo, 1990; Payne et al., 1990; Kraus and Kenney, 1991).

Had funding been available, it would have been interesting to have conducted aerial surveys further to the east on the Nova Scotian shelf, from La Have Bank eastward to Emerald Bank and the western end of Sable Island Bank (all east of the boundary on Figs 1 and 2) in May-July 1992. That was the location of a significant number of right whale sightings made by whalers operating out of Blandford, Nova Scotia from 1966-1972 (Mitchell et al., 1986). The area between La Have and Emerald Banks was the location of most of their July sightings, as well as some in August and a few in June. Interestingly enough, the DFO fishery observer data for 1992 did include five sightings in that vicinity in April and May, although there are no data available for other years which might allow assessment of whether low numbers of right whales routinely occur in Nova Scotian shelf waters in most or all years.

\section{Factors influencing cetacean distributions}

What factors could be responsible for the anomalies in right whale distribution patterns observed in 1992 in the Gulf of Maine? It has been relatively well-established that the distributions of cetaceans are strongly affected by the distribution, abundance and patchiness of their prey populations (CETAP, 1982; Gaskin, 1982; Kenney and Winn, 1986b; Katona and Whitehead, 1988). The question then is, what was different about the prey resource exploited by Gulf of Maine right whales in 1992, and why? Spring zooplankton densities in the Great South Channel are among the highest published for any area of the western North Atlantic (CETAP, 1982; Scott et al., 1985; Sherman et al., 1987; Wishner et al., 1988; 1995; Durbin et al., 1995c; Macaulay et al., 1995; Beardsley et al., 1996; Meise and O'Reilly, 1996), although even higher densities have been measured in small patches near feeding right whales in Cape Cod Bay (Mayo and Goldman, 1992; C.A. Mayo, Center for Coastal Studies, pers. comm.). The question posed above can thus be refined to, what was different about zooplankton distribution and abundance in the western Gulf of Maine in 1992, and why?

The characteristics of the zooplankton community which make a specific area a desirable right whale feeding ground include the species composition, the abundance of the preferred species, the age (therefore size) structure of the preferred species and the patch structure (Kenney et al., 1986a; Wishner et al., 1988; 1995; Murison and Gaskin, 1989; Mayo and Marx, 1990; C.A. Mayo, Center for Coastal
Studies, pers. comm.). All of these are affected by physical parameters and processes. Temperature can affect species composition directly, since each zooplankton species may have differing thermal preferences and physiological optima. Temperature and hydrography affect phytoplankton productivity and therefore zooplankton growth, productivity and abundance. Temperature affects growth and developmental rates, and therefore age and size. Temperature, hydrography and phytoplankton productivity can all affect the patch structure of the zooplankton. Temperature changes can affect or be caused by changes in circulation patterns, which influence advection of zooplankton.

\section{Anomalous GSC zooplankton community in 1992}

The available data for the GSC in 1992 show that the species composition of the zooplankton community, the abundance of zooplankton species, the water temperatures and the water column structure were all different from earlier years. Copepod abundances were greatly decreased, Calanus finmarchicus was in nearly equal abundance to other copepod taxa rather than strongly dominant, and the pteropod Limacina retroversa was the dominant zooplankter. Temperatures were significantly colder than normal, and the establishment of the expected hydrographic structure, i.e. the frontal zone between stratified and tidally-mixed water masses, was apparently delayed. Right whales either did not appear, or visited the region and quickly departed, so the most likely explanation is that something about the prey resource in the GSC in 1992 was sub-optimal.

Hypothesis 1 - pteropods are not acceptable prey One possibility is that pteropods are not acceptable right whale prey for one or more of several different reasons:

(1) Right whales find pteropods distasteful. Pteropods can contain a black pigment with a sulphur-containing compound (dimethylsulphoniopropionate or DMSP) which they get from certain phytoplankton food, especially Phaeocystis and coccolithophores (Lalli and Gilmer, 1989; Keller, 1991; Liss et al., 1994). Fish which have been feeding on pteropods are referred to by fishermen as 'black guts' or 'stinkers,' because the pigment leaches into and discolours the viscera and flesh, and the DMSP breaks down to dimethyl sulphide (DMS), causing an unpleasant odour (Wimpenny, 1966; Lalli and Gilmer, 1989). Perhaps either DMSP or DMS make pteropods taste objectionable to right whales. This does not seem likely, however. Descriptive publications on zooplankton or marine biology often mention that pteropods are fed upon by whales (e.g. Pratt, 1935; McConnaughey, 1978; Lalli and Gilmer, 1989), although the whale species is seldom clearly specified. Pratt (1935), for example, states that Limacina is 'an important food of whales' and that Clione 'forms an important source of food for right whales', though both statements are unsupported by literature citation and 'right whale' could refer to the bowhead ('Greenland right') whale. In addition, there are rare references in the cetacean literature to pteropods as right whale prey (Millais, 1906; Hentschel, 1937 - not seen, cited in both Tomilin, 1957 and Slijper, 1962; Gaskin, 1982), and somewhat more common mentions of pteropods as bowhead whale prey (Hjort and Ruud, 1929; MacGinitie, 1955; Tomilin, 1957; Marquette, 1978; Lowry and Frost, 1984; Lowry, 1993). Finally, right 
whales have recently been observed in the Bering Sea in the midst of a coccolithophore bloom, suggesting that the whales were not especially sensitive to the DMS produced by the bloom (C. Tynan, NMFS, pers. comm.).

(2) The size and/or shape of pteropods makes filtration through right whale baleen difficult or inefficient. It is unlikely that this is the case based on size alone. Mayo (pers. comm.) tested the filtration efficiency of a section of right whale baleen collected from a stranded animal. He found a direct correlation between zooplankter size and baleen filtration efficiency, with $89 \%$ efficiency for the largest zooplankton size class tested, 505-700 $\mu \mathrm{m}$ (defined by the mesh sizes of filters used to sort the zooplankton samples into size categories). The shell diameter of adult Limacina retroversa ranges from $2,000-7,000 \mu \mathrm{m}$, with the total size of the animal larger, varying depending on the degree of extension of the foot (Hardy, 1956; Wimpenny, 1966; Lalli and Gilmer, 1989). The individuals in the GSC in 1992 represented a range of ages and were on the smaller end of that size range at $0.5-2 \mathrm{~mm}$, which was slightly smaller than the 1.2-2mm Calanus sampled at the same time (Gallager et al., 1996). Lowry and Frost (1984) found prey items of $3-30 \mathrm{~mm}$ in bowhead whale stomach contents. Mayo (pers. comm.) tested only crustacean zooplankton, so it is not possible to address at this time whether pteropod shape or surface characteristics may affect filtration efficiency.

(3) Pteropods swim too fast to be effectively captured by right whales. This possibility may be considered as unlikely based on indirect evidence. Zooplankton nets are generally towed at about $1 \mathrm{knot}(1.9 \mathrm{~km} / \mathrm{hr})$, about the same as or slightly slower than the swimming speed of a feeding right whale (Watkins and Schevill, 1976; 1979; Mayo and Marx, 1990). Therefore, zooplankton species which readily avoid capture by nets might also avoid capture by right whales. Because of their faster swimming speeds, krill (Meganyctiphanes and Thysannoesa in the Gulf of Maine), are under-sampled due to net avoidance (Brodie et al., 1978; Wishner et al., 1988; 1995; Macaulay et al., 1995). However, pteropods can be collected readily by plankton nets (Hardy, 1956; Sherman et al., 1987; Lalli and Gilmer, 1989; K. F. Wishner, pers. comm.) and probably also by right whales.

Hypothesis 2 - pteropod patch density was energetically inadequate

A second and more likely possibility is that pteropods are acceptable right whale prey, but in 1992 they were not aggregated into patches dense enough to provide a net energetic gain to feeding right whales, even though their average abundance was only slightly lower than the average abundance of Calanus in 1989, a year when right whales were feeding in the GSC. Kenney et al. (1986a) and Mayo and Marx (1990) have shown that right whales need prey concentrated above some threshold density (on the order of $10^{4}-10^{5} / \mathrm{m}^{3}$ ) to obtain a net energetic benefit from feeding. Pteropod populations in the GSC in 1992 were distributed throughout the water column, with an average water column abundance of $235,000 / \mathrm{m}^{2}$ and a maximum measured patch density (at a depth of $12 \mathrm{~m}$ ) of $3,700 / \mathrm{m}^{3}$ (K.F. Wishner, pers. comm.). Calanus in 1989, with only slightly higher average water column abundance $\left(255,000 / \mathrm{m}^{2}\right)$, was horizontally and vertically aggregated, with a relatively thin near-surface layer in one location containing a maximum measured patch density of $331,000 / \mathrm{m}^{3}$ (Wishner et al., 1995). Mayo (pers. comm.) has found that the threshold zooplankton density which triggers right whale feeding behaviour in Cape Cod Bay is about $4,000 / \mathrm{m}^{3}$, slightly higher than the peak pteropod density measured in the GSC in 1992.

Gallager et al. (1996) reported the results of a Video Plankton Recorder (VPR) towyo transect across the GSC at about $41^{\circ} 17^{\prime} \mathrm{N}$ on $27-28$ May 1992. Because the VPR photographically samples very small volumes at 60 samples per second, it can measure micro-scale $(<1 \mathrm{~m})$ zooplankton patch densities. The peak density they detected for a single sample within a patch of Limacina was $7,000 / \mathrm{m}^{3}$. Interestingly, they observed some adult Limacina near the surface to be releasing streamers of embryos, with the peak density of embryos over $6,000,000 / \mathrm{m}^{3}$, however at only $200 \mu \mathrm{m}$ the embryos are too small to be effectively filtered by right whale baleen (C.A. Mayo, pers. comm.).

Differences in caloric content between Calanus and Limacina may further decrease the relative food value of the latter to right whales. Calanus is relatively high in energy content, approximately 4,000-8,000 cal/gm dry weight, varying with season and life-stage (Comita et al., 1966; Lawrence, 1976). Clione limacina, an Arctic pteropod eaten by bowhead whales (Lowry and Frost, 1984), has a caloric density of 3,310-4,000 cal/gm dry weight (Percy and Fife, 1981). Clione is a shell-less species (Hardy, 1956; Lalli and Gilmer, 1989). Limacina should have an even lower caloric density, since the shell would add to the weight but not the energy content.

\section{Pteropods in the GSC before 1992}

The presence of pteropods in 1992 in the GSC region is neither unprecedented nor necessarily anomalous. Sherman et al. (1987) summarised the NMFS zooplankton data for Georges Bank and adjacent waters, with their 'northern deep water' zone approximately equivalent to the GSC region. They showed that pteropods were a normal component of the zooplankton of the area, comprising over $80 \%$ of the non-copepod zooplankton in late spring and early summer with a peak occurrence in June. Their peak average pteropod density was approximately one-fifth the magnitude of and somewhat later than the peak average Calanus density. The observed dominance of pteropods in 1992 may simply have resulted from the very reduced populations of Calanus in the GSC, without substantial differences in pteropod abundance from previous years.

\section{Temperature and hydrographic effects on GSC zooplankton}

It is unlikely that temperature or hydrography affect right whale distribution in the GSC directly. Right whales are well-insulated by a thick blubber layer, and have been sighted in water as cold as $2.2^{\circ} \mathrm{C}$ off the northeast US coast (Winn et al., 1986). They also have been observed in recent years as far north as Greenland and Iceland (Knowlton et al., 1992). It is similarly unlikely that the cooler temperatures in 1992 affected GSC zooplankton by a direct thermal effect, i.e. by being below the range of temperatures at which Calanus can persist. Calanus and Pseudocalanus are boreal species which are the dominant copepod taxa in the Gulf of Maine/Georges Bank region in winter and spring, and are largely replaced in summer by a warmer-water assemblage dominated by Metridia lucens and Centropages typicus (Sherman et al., 1987). During the warmer part of the year in the Gulf of Maine/Georges Bank region, Calanus abundance 
is consistently higher in colder water masses (Meise and O'Reilly, 1996). However, it is probable that the hydrography of the GSC has a significant effect on the development of the extremely dense zooplankton patches on which right whales feed. Gaskin $(1987 ; 1991)$ and Murison and Gaskin (1989) showed that the boundary zones between stratified and mixed water masses off Nova Scotia were important in the formation of dense Calanus patches. Similar processes, probably augmented by the behaviour of the copepods themselves, are believed to be responsible for zooplankton patch structure in the GSC (Scott et al., 1985; Wishner et al., 1988; SCOPEX results - see below; Miller et al., 1998). The low temperatures and anomalous hydrographic structure in the GSC in 1992 probably did not cause the observed absence of right whales in the region directly, but rather indirectly through effects on the zooplankton.

The results of the SCOPEX study of the oceanography of the GSC relative to right whale ecology enable further refinement of the hypothesis that low temperatures and delayed development of stratification in 1992 affected the regional zooplankton community and, therefore, right whales. To briefly summarise the conclusions of the study:

(1) patterns of right whale occurrence in the GSC are directly related to the occurrence of dense patches of Calanus finmarchicus (Kenney et al., 1995; Macaulay et al., 1995; Wishner et al., 1995; Beardsley et al., 1996);

(2) right whale distribution and feeding is also strongly correlated with the proportion of larger, more energy-dense Calanus life stages (fourth- and fifth-stage copepodites and adults - Wishner et al., 1995);

(3) observed interannual differences in the location of the main right whale aggregation are correlated with sea surface temperatures north of the tidal mixing front in early May, with the aggregation usually on the west side of the region, but on the east side in colder years (Kenney et al., 1995);

(4) the development of exceptionally dense Calanus patches is principally a result of hydrographic processes, with the copepods being advected into the GSC region and concentrated rather than growing in situ as a result of trophic processes (Wishner et al., 1988; 1995; Chen et al., 1995a; b; Durbin et al., 1995b) - concentration is probably enhanced by the behaviour and swimming of the copepods, i.e. swarming and diel vertical migration (Beardsley et al., 1996); the Calanus which aggregate in the GSC likely originate from source regions throughout the Gulf of Maine and Nova Scotian shelf (Bucklin and Kocher, 1996; Miller et al., 1998);

(5) the general circulation in the region is cyclonic with the main currents entering from the northwest, flowing southeastwards to the centre of the region and then turning to the northeast along the flank of Georges Bank (Chen et al., 1995a; Fig. 3);

(6) Calanus growth and development is temperature dependent, with faster rates in warmer temperatures (Durbin et al., 1995a);

(7) when water temperatures early in the season are lower, Calanus development from one stage to the next is slower, and consequently the location where the proportion of C-4 and larger stages preferred by right whales is reached is on the east side of the area, rather than the west (Durbin et al., 1995a; Kenney et al., 1995; Wishner et al., 1995).

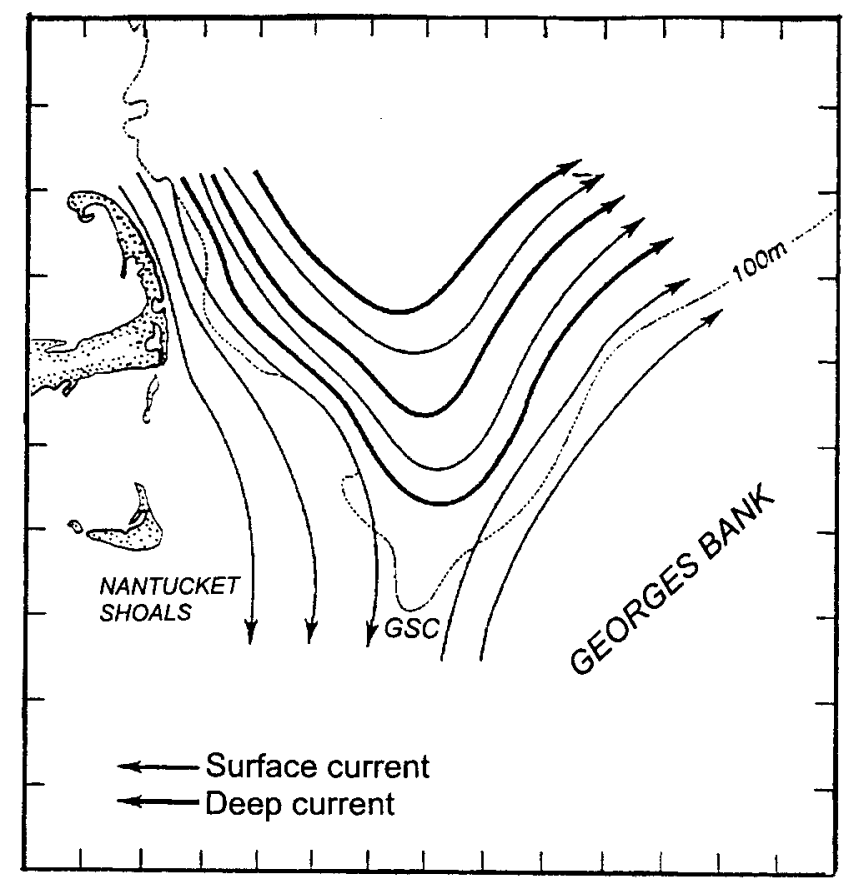

Fig. 3. Simplified conceptual model of the surface and deeper circulation in the Great South Channel region during late spring, based on SCOPEX Acoustic Doppler Current Profiler and satellite-tracked drifter data (from Chen et al., 1995b). The tidal mixing front which is usually established during spring and summer approximately follows the $100 \mathrm{~m}$ isobath, with north-south oscillations on a tidal cycle.

Extension of this scenario then illuminates what may have occurred in 1992 . With water temperatures averaging $2-6^{\circ} \mathrm{C}$ colder than in previous years, the Calanus cohort did not mature to C-4 until after the currents had moved them through and beyond the GSC region. The high proportions of large copepods preferred by right whales were never attained within the area. (Substantial increases in current velocity could have the same effect as reduced temperature by advecting the growing cohort through the region more quickly. This was probably unlikely in 1992 - see discussion under Labrador Current below.) Additionally, the degree of Calanus diel vertical migration is often tied to ontogeny, with younger-stage individuals typically remaining more in surface waters and older-stage copepodites and adults more likely to strongly migrate (Marshall and Orr, 1972; Williams and Lindley, 1980; Durbin et al., 1995c). Since vertical migration may be involved in their concentration by hydrographic processes, delayed initiation of migration may have enhanced the advection of Calanus through and out of the area without the development of dense patches. Two observations from 1992 provide additional support for this hypothesis: (1) the area of the late spring/early summer right whale sightings, in the central Gulf of Maine, is northeast and 'downstream' of the GSC, and where one might expect to find Calanus populations which have been advected through the GSC by currents; (2) a Sea Education Association (SEA) cruise which went to the GSC area in June with the objective of sighting right whales and sampling zooplankton in their vicinity, but failed to locate any right whales, did collect some zooplankton samples with high Calanus densities in the northeast portion of the area, near the northern edge of Georges Bank (M. Lesser, SEA, pers. comm.).

Even though the GSC was apparently not an acceptable right whale feeding ground in May and June 1992, some very dense copepod patches were present nevertheless. The VPR 
transect on 27-28 May (Gallager et al., 1996) showed a horizontal patch of Calanus finmarchicus, about $2 \mathrm{~km}$ in width and at a depth of about $15-20 \mathrm{~m}$ within and just above the thermocline, with densities exceeding $2,500 / \mathrm{m}^{3}$ throughout and a peak density of $285,000 / \mathrm{m}^{3}$. They also observed a peak patch density of $3,000,000 / \mathrm{m}^{3}$ for Pseudocalanus $\mathrm{sp}$. The simultaneous hydrographic data they collected during their transect showed that the GSC is extremely complex. Within one east-west transect, they observed twelve different identifiable water masses or types. Limacina and Calanus were found primarily within the same water masses, but were very different in their fine-scale distributions. Limacina was densest in the centre of the water mass, where the temperature gradient was smallest, leading to low stability and high mixing. Calanus was densest at the lower edge of the water mass in/near the thermocline, where stability and resistance to mixing is highest. This seems to support the SCOPEX hypothesis that species-specific behaviour enhances the physical aggregation of Calanus in the GSC (Kenney and Wishner, 1995; Beardsley et al., 1996), although Miller et al. (1998) have suggested that strictly physical mechanisms may be sufficient.

\section{Underlying physical factors in 1992}

There are several large-scale oceanographic or atmospheric phenomena which may have influenced the temperature and hydrography within the GSC region in 1992, thereby leading to a different pattern of zooplankton occurrence and the subsequent absence of right whales. These include the North Atlantic Oscillation, the Gulf Stream, the Labrador Current and associated inputs, North Atlantic thermohaline circulation and the cooling effect of the 1991 Pinatubo eruption. Many of these vary on decadal or longer time scales, so information on short-term variability or anomalies is rare. In addition, the atmosphere, surface currents and deep circulation of the North Atlantic are probably inter-connected in some complex manner which as yet is not fully understood (Reid et al., 1998). Finally, the lack of directed right whale surveys in the GSC in 1993 and subsequent years has made it very difficult to establish whether the absence of right whales there in 1992 was a one-time anomaly or the beginning of a longer-term change in their distribution. However, even though there are no GSC survey or sightings data for 1993-1997, there were between one and ten right whale photo-identifications in the GSC during the March-June period each year which have been included in the catalogue from a variety of sources. Therefore, right whales have not been entirely absent in spring from the GSC in later years like they were in 1992, which suggests that their absence in 1992 was, in fact, a single-year anomaly.

\section{North Atlantic Oscillation}

The North Atlantic Oscillation (NAO) is a pattern of alternating phases in atmospheric pressure between Iceland and the Azores, leading to different patterns of jet stream trajectory, winds and weather at both extremes of the cycle (van Loon and Rogers, 1978; Hurrell, 1995). The dimensionless NAO index is the standardised difference between the Iceland and Azores pressures, and is calculated on a monthly basis. Because the impact of NAO fluctuations is most apparent during the winter, standard practice is to average the monthly values across four or five months, December through March or April (Hurrell, 1995; Fromentin and Planque, 1996). Positive values of the winter NAO correspond to cold winters in Greenland and Iceland and mild winters in Europe, while negative values correspond to relatively warmer Greenland and colder European winters, and the index tends to remain in one phase or the other for some number of successive years, then switch to the opposite phase (Hurrell, 1995).

Fromentin and Planque (1996) showed that the NAO can influence Calanus finmarchicus and $C$. helgolandicus abundance in the eastern North Atlantic around the British Isles. Changes in NAO cause changes in the relative strength of west wind stress, which lead to changes in water temperature patterns, frequency and intensity of upwelling and phytoplankton productivity, all of which influence zooplankton populations. To test whether a short-term change in the NAO, or a recent switch from one state to the other, may have affected the GSC in 1992, monthly NAO index data for 1980-1998 were obtained from the Climate and Global Dynamics Division, National Center for Atmospheric Research (http://www.cgd.ucar.edu/cas/ climind/nao_monthly.html). The winter mean index for a given year was calculated from the four monthly values from December of the previous year through March, following Hurrell (1995). The 1992 value was 0.975, which is not significantly different from the 1980-1991 average of 0.670 $(\mathrm{SE}=0.316$; range $=-0.775$ to 3.959$)$. The NAO has been in a largely positive phase in the 1980s and 1990s (Hurrell, 1995), with a period of very high values from 1989-1995 (the three highest values recorded were in 1989, 1994 and 1995). There is no obvious short-term fluctuation in or shortly preceding 1992 in the time-series, and the index had been in a positive phase for about a decade before 1992. The most obvious change in the time series is the large increase in 1989 , and one would have to both presume a three-year time lag for an effect on right whales in 1992, and expect the effect to have persisted until 1998, which does not appear to be the case. For comparative purposes, during the late 1960s and early 1970 s, when there were substantial numbers of right whale sightings on the Nova Scotian shelf (Mitchell et al., 1986), there was a strongly negative phase of the NAO, quite different than the more recent period (Hurrell, 1995).

\section{Gulf Stream}

The Gulf Stream is a north and eastward-flowing, warm, western boundary current in the western North Atlantic. Taylor et al. (1992) and Taylor (1995) have shown that interannual variability in the latitudinal position of the north wall of the Gulf Stream in the western North Atlantic can be correlated with variability in zooplankton abundance in the eastern North Atlantic. Taylor $(1995 ; 1996)$ developed the Gulf Stream Index (GSI), a single dimensionless number based on mean monthly Gulf Stream position (calculated from the first principal component of latitude where the current crosses six different meridians of longitude). The monthly and annual mean GSI data were obtained from the Plymouth Marine Laboratory (http://www.pml.ac.uk/pml/ srpl/gulfstream/inetdat.htm). Examining the annual means, there was no short-term anomaly in 1992. The value in 1992 was 1.208 , which was a slight decrease from a value of 1.359 in 1991 . The index was continuously positive from 1988 to the maximum value of 2.264 in 1995. Interestingly, approximately $60 \%$ of the interannual variability in Gulf Stream position can be attributed to variability in the NAO (Taylor et al., 1998), and this period of continuously positive GSI corresponds very closely to the series of high NAO years. One might therefore have expected either both indices to show some short-term fluctuation which could be related to the 1992 changes in the GSC, or that neither would, which appears to be the case. 
Hays et al. (1993) showed a strong linear relationship between GSI and annual mean total copepod abundance for an area in the vicinity of the shelf break between Scotland and the Faroe Islands. The relationship held from 1966-1988, but beginning in 1989 copepod abundance was significantly lower than predicted from their model. Again, that period coincides with the time of very high NAO values, although no connection was established in their results.

\section{Labrador Current}

A dominant influence on the properties and circulation of water in the Gulf of Maine is the influx of cooler, somewhat fresher water flowing southwestward across the Nova Scotian shelf and inward at depth through the Northeast Channel (Chapman and Beardsley, 1989; Townsend, 1992; Petrie and Drinkwater, 1993; Khatiwala and Fairbanks, 1999). Buoyancy forcing from this inflow is the major driver of Gulf of Maine circulation, and the freshwater inputs are derived about one-third from the St. Lawrence River and two-thirds from high latitude inputs (glacial melt and river run-off) into polar waters feeding into the Labrador Sea and Labrador Current, with only a small contribution from local river inputs (Khatiwala and Fairbanks, 1999). Petrie and Drinkwater (1993) described a widespread cooling and freshening trend across the Scotian shelf and Gulf of Maine from 1952-1967, during which time there was a quadrupling in transport of the Labrador Current, followed by a reversal. The period 1952-1967 was a time of steady decrease in long-term average NAO (Hurrell, 1995), however Petrie and Drinkwater (1993) were unable to correlate variability in Labrador Current transport with NAO. Labrador Current transport is a much more difficult parameter to measure than simple atmospheric pressure at two locations (Han and Tang, 1999), so there is no readily accessible data time-series available for correlation.

Bisagni et al. (1996) described a substantial influx of cold Scotian Shelf Water (SSW, identified by salinity less than 32.0 psu) onto Georges Bank in April 1992. They reviewed the occurrence of SSW on Georges Bank from available hydrographic data going back to 1912. Typically, the peak near-surface flow of SSW westward just south of Nova Scotia into the Gulf of Maine occurs in February. There is also a so-called 'cold band' of SSW extending westward along the southern edge of Georges Bank. In 30\% of the years where there were appropriate data, SSW could be detected on the southern flank of Georges Bank in May (from where clockwise circulation around the bank advects the water into the GSC). In 1992, temperatures within the SSW cold band were below $2^{\circ} \mathrm{C}$ in February. SSW was observed on the bank in April, which was not seen in any previous year. Colder than normal conditions persisted throughout the spring of 1992 all along the southern flank of Georges Bank (Bisagni et al., 1996), with seasonal warming increasing the temperature within the SSW plume to $6-7^{\circ} \mathrm{C}$ by early June. Monthly average water temperatures at a meteorological buoy on southern Georges Bank were up to $3{ }^{\circ} \mathrm{C}$ colder than the long-term means. Conditions on southern Georges Bank returned to 'normal' in 1993, so the patterns observed in 1992 were a short-term phenomenon (Bisagni et al., 1996).

The strong influx of colder SSW onto Georges Bank and then into the GSC in 1992 is probably the immediate cause of the reduced temperatures observed in the GSC, however its underlying cause is not clear. Bisagni et al. (1996) hypothesised that the large influx of SSW in 1992 was consistent with higher than average discharge from the St Lawrence River the preceding year, since the peak SSW inflow lags the peak river discharge by about nine months. However, they were unable to correlate longer-term variability in SSW with lagged variability in St Lawrence discharge and suggested that other factors were likely involved. SSW is the end of the Labrador Current branch which flows south of Nova Scotia (Chapman and Beardsley, 1989). Although no Labrador Current transport data are available for 1992, a hypothesis of higher transport in and preceding 1992, when NAO was high, would not be consistent with the observations of Petrie and Drinkwater (1993) of high transport during a period of low NAO.

Presuming that near-surface SSW influx south of Nova Scotia was also greater in 1992, one might expect that enhanced buoyancy forcing might have intensified the Gulf of Maine circulation, increasing current velocities through the GSC. This would have the same effect as lower temperature on shifting the location of Calanus maturation to the 'whale-food' size class further eastward. Lacking current data, this possibility is difficult to address. However, the hydrographic data from the 27-28 May transect by Gallager et al. (1996) showed the leading edge of the surface plume of warmer, fresher water derived from coastal rivers in New England had just reached the extreme western end of their transect. This is similar to the conditions observed in 1988, when current velocities were lower than in 1989 (Chen et al., 1995a; b).

\section{Thermohaline circulation}

Saline Gulf Stream water transported to high latitudes mixes with colder Arctic waters, then cools during the winter forming very cold, salty water which sinks because of its increased density. In the Labrador Sea between Labrador and Greenland, the process causes the development of a water mass at mid-depths known as Labrador Sea Water (LSW), while North Atlantic Deep Water (NADW) is formed in the Greenland and Irminger Seas north and west of Iceland (Sverdrup et al., 1942). These water masses flow slowly southward at depth, eventually remixing to the surface in a gradual convective cycle at a time scale on the order of a thousand years (Sverdrup et al., 1942). Recent work has shown than NAO variability has a strong effect on the formation of these water masses. Under high NAO conditions, formation of NADW is inhibited and that of LSW is enhanced, and the opposite occurs under low NAO (Reid et al., 1998). The period of very high NAO between 1989 and 1995 was a time of greatly enhanced LSW formation (Curry and McCartney, 1996; Reid et al., 1998). However, the transport rates of deep water masses are very slow; Read and Gould (1992) estimated that it took 18 or 19 years for LSW to reach the area west of Ireland. Because of the slow flows and long time scales, it seems unlikely that fluctuations in rates of deep water formation could cause short-term fluctuations in hydrography in the Gulf of Maine.

Reid et al. (1998) suggested that deep convective circulation, surface circulation and atmospheric cycles in the North Atlantic are inter-related in some complex, not well-understood manner. The data summarised in Curry and McCartney (1996) show a strong freshening of LSW during the 1990s period of high NAO and enhanced LSW formation. This suggests that Labrador Current transport of lower salinity water at the surface might be reduced at the same time. Conversely, Labrador Current transport increased in 1952-1967 (Petrie and Drinkwater, 1993) while NAO, deep convection in the Labrador Sea and LSW formation were low (Read and Gould, 1992; Curry and McCartney, 1996). If there is some degree of inverse relationship between Labrador Current transport and NAO, 
perhaps transport has been reduced during the 1990s, weakening the Gulf of Maine circulation. This might have an effect on GSC hydrography, however it seems that the effect would be over a longer term and not in a single year, as observed.

\section{Global cooling from the Pinatubo eruption}

One other potentially important factor in the significantly lower ocean temperatures in the GSC in the spring and summer of 1992 is the 15 June 1991 eruption of Pinatubo volcano on Luzon Island in the Philippines (Bernard et al., 1991; Luhr, 1991; Brasseur and Granier, 1992). The eruption plume included an estimated 20 million metric tons of sulphur dioxide (two-thirds of the total aerosols produced during the eruption) ejected to altitudes of 20-30km (Bluth et al., 1992; Brasseur and Granier, 1992). The $\mathrm{SO}_{2}$ gas became a long-lasting aerosol haze of sulphuric acid, which significantly reduced the amount of solar radiation reaching the surface (Luhr, 1991; Brasseur and Granier, 1992; Kerr, 1993; Blumthaler and Ambach, 1994; McCormack et al., 1995). The aerosol clouds completely circled the globe within 22 days after the main eruptions, and eventually extended into most of the Northern and Southern Hemispheres (Bluth et al., 1992).

Hansen et al. (1992) predicted in advance, based on a simplified computer model of the atmosphere, that the cooling effect from the Pinatubo eruption would be widespread, lowering the mean global temperature by $0.5^{\circ} \mathrm{C}$ for 1992, 1993 and possibly 1994. Atmospheric temperature measurements from satellites showed a decrease in global mean temperature for the 12 months following the eruption of $0.6^{\circ} \mathrm{C}$ from the year preceding the eruption (Dutton and Christy, 1992; Kerr, 1993; McCormack et al., 1995). The average temperature in 1992 was $0.5^{\circ} \mathrm{C}$ below the long-term mean and 1993 was $0.2^{\circ} \mathrm{C}$ below, while 1994 saw a return to the pre-eruption warming trend (McCormack et al., 1995). Additionally, the cooling effect was not evenly distributed in space and time. The most intense cooling, greater than $1.0^{\circ} \mathrm{C}$ below the long-term mean, was in the middle latitudes of the Northern Hemisphere between March and August of 1992 (Dutton and Christy, 1992; Kerr, 1993). It should be noted that all of these temperature data were based on satellite measurement of atmospheric temperatures in the lower troposphere, and that no studies of effects of Pinatubo cooling on ocean temperatures have been published, although a reduction in the intensity of solar radiation could be expected to retard warming of surface waters. On the other hand, regional and local effects, some dramatic, of the cooling were seen on land. Jones and Kelly (1996) showed decreases in 1992 surface temperatures measured at land-based weather stations attributed to the Pinatubo cooling effect, with the most intense cooling in eastern North America. Abdalati and Steffen (1997) showed that ice-sheet melting in Greenland decreased by $68 \%$ in 1992 over 1991, while Shuman et al. (1996) showed a $2^{\circ} \mathrm{C}$ negative temperature anomaly in 1992 at a station in the centre of the Greenland ice-sheet.

Air temperatures in 1992 in southeastern New England were significantly lower than normal. Monthly summary data from the National Weather Service station at Chatham, Massachusetts (Fig. 1; located at the 'elbow' of Cape Cod and therefore the station closest to the GSC area) showed that average daily minimum, mean and maximum temperatures at Chatham in March, April and May 1992 were all $2.2-3.3^{\circ} \mathrm{F}\left(1.2-1.8^{\circ} \mathrm{C}\right)$ below the $1979-1991$ averages (Table 4; NCDC, 1979-1992). In fact, for the two-month period of March and April 1992 for the entire
New England region, 'the combined March/April average for the region was $2.8^{\circ}$ below normal, which was the coolest such combination since 1978' (NCDC, 1992, no. 4).

Tablc 4

Average daily minimum, mean and maximum air temperatures $\left({ }^{\circ} \mathrm{F}\right)$ at the Chatham, Massachusetts National Weather Service station in March, April, May and June of 1992 compared to 1979-1991 averages (NCDC, 1979-1992).

\begin{tabular}{lccc}
\hline Month(s) & Minimum & Mcan & Maximum \\
\hline March 1992 & 29.5 & 34.8 & 40.1 \\
March 1979-91 & 31.7 & 37.6 & 43.4 \\
April 1992 & 36.3 & 42.1 & 47.9 \\
April 1979-91 & 39.4 & 45.1 & 50.8 \\
May 1992 & 45.0 & 51.3 & 57.6 \\
May 1979-91 & 47.5 & 53.7 & 59.8 \\
June 1992 & 55.7 & 62.1 & 68.4 \\
June 1979-91 & 55.4 & 61.8 & 68.3 \\
\hline
\end{tabular}

\section{Conclusions}

The absence of right whales in the GSC in 1992 was probably a direct result of the lack of sufficiently dense patches of Calanus finmarchicus, their preferred prey. The pteropod populations which were present may have been unacceptable prey for right whales regardless of density, but more likely were not aggregated into sufficiently dense patches for efficient right whale feeding. These changes in the GSC zooplankton community probably resulted from a significant decrease in water temperature, and consequent changes in circulation and mixing patterns and water structure.

The direct cause of the observed 1992 GSC temperature and hydrographic anomalies appears to be an anomalous influx of cold Scotian Shelf Water which began in late winter and resulted in below-average temperatures over much of Georges Bank through the spring (Bisagni et al., 1996). The underlying cause of this phenomenon is not clear, although it appears that high discharge from the St. Lawrence River in 1991 is involved. It is also possible that reduced air temperatures related to global cooling caused by atmospheric sulphate aerosols from the eruption of Mount Pinatubo in June 1991 may have exacerbated the effect by retarding the seasonal warming of surface waters. Fluctuations in other phenomena, including the Labrador Current, Gulf Stream, North Atlantic Oscillation, and Labrador Sea Water formation may all affect hydrography within the Gulf of Maine and Great South Channel, however the time-scales of variability are longer, and no short-term anomalies have been observed which can be related to the 1992 anomalies in GSC hydrography, zooplankton, and right whale occurrence.

\section{ACKNOWLEDGEMENTS}

This study was initially funded by a Marine Mammal Commission (MMC) grant (T94070648) to the University of Rhode Island (URI), with most of the funds provided to the Commission from the National Marine Fisheries Service (NMFS). The aerial survey time was supported by MMC grant T94070635 to Aero-Marine Surveys, Inc. and by grant NA-90-AA-H-CE464 from NMFS to URI through the URI/NOAA Cooperative Marine Education and Research (CMER) programme. Subsequent work on the paper was 
supported by NMFS/CMER grant NA-67-FE-0383. NMFS has supported portions of the cooperative programme since 1986, including the Center for Coastal Studies and New England Aquarium surveys, analysis and curation of photographs at the Aquarium and overall database management at URI. NMFS permitted Jim Hain to participate in some of the surveys, and supported his travel. Scott Kraus and Phil Hamilton (New England Aquarium), Stormy Mayo (Center for Coastal Studies), Moira Brown (East Coast Ecosystems), Jim Hain (NMFS), Jerry Conway (Canadian Dept. of Fisheries and Oceans) and others provided valuable right whale sightings and photo-identification data. Karen Wishner and Jennifer Saltzmann (URI), kindly provided the 1992 zooplankton information. Bob Griffin and Peter Cornillon from URI and the Northeast Area Remote Sensing facility provided real-time AVHRR satellite images in 1992, and Shannon Wagner (University of Massachusetts-Dartmouth), assisted with archived AVHRR data. Jim Bisagni (University of Massachusetts-Dartmouth), was extremely helpful in pointing out critical literature sources. Valuable criticisms of this manuscript were provided by Greg Silber (MMC), Jim Hain (NMFS), Bob Beardsley (Woods Hole Oceanographic Institute), Cyndi Tynan (NMFS) and an anonymous reviewer.

\section{REFERENCES}

Abdalati, W. and Steffen, K. 1997. The apparent effects of the Mt. Pinatubo eruption on the Greenland ice sheet melt extent. Geophys. Res. Lett. 24:1,795-97.

Beardsley, R.C., Epstein, A.W., Chen, C., Wishner, K.F., Macaulay, M.C. and Kenney, R.D. 1996. Spatial variability in zooplankton abundance near feeding right whales in the Great South Channel. Deep-Sea Res. II 43(7-8):1,601-625.

Bernard, A., Demaiffe, D., Mattielli, N. and Punongbayan, R.S. 1991. Anhydrite-bearing pumices from Mount Pinatubo: further evidence for the existence of sulpher-rich silicic magmas. Nature, Lond. 354:139-40

Bisagni, J.J., Beardsley, R.C., Ruhsam, C.M., Manning, J.P. and Williams, W.J. 1996. Historical and recent evidence of Scotian Shelf Water on southern Georges Bank. Deep-Sea Res. 43:1,439-71.

Blumthaler, M. and Ambach, W. 1994. Changes in solar radiation fluxes after the Pinatubo eruption. Tellus 43B:76-8.

Bluth, G.J.S., Doiron, S.D., Schnetzler, C.C., Krueger, A.J. and Walter, L.S. 1992. Global tracking of the $\mathrm{SO}_{2}$ clouds from the June, 1991 Mount Pinatubo eruptions. Geophys. Res. Lett. 19:151-54.

Braham, H.W. and Rice, D.W. 1984. The right whale, Balaena glacialis. Mar. Fish. Rev. 46:38-44.

Brasseur, G. and Granier, C. 1992. Mount Pinatubo aerosols, chlorofluorocarbons, and ozone depletion. Science 257:1,239-41

Brodie, P.F., Sameoto, D.D. and Sheldon, R.W. 1978. Population densities of euphausiids off Nova Scotia as indicated by net samples, whale stomach contents, and sonar. Limnol. Oceanogr. 23(6): 1,264-267.

Brown, C.W. and Winn, H.E. 1989. Relationship between the distribution pattern of right whales, Eubalaena glacialis, and satellite-derived sea surface thermal structure in the Great South Channel. Cont. Shelf Res. 9(3):247-60.

Bucklin, A. and Kocher, T.D. 1996. Source regions for recruitment of Calanus finmarchicus to Georges Bank: evidence from molecular population genetic analysis of mtDNA. Deep-Sea Res. 43:1,665-81.

CETAP. 1982. A Characterization of Marine Mammals and Turtles in the Mid- and North Atlantic Areas of the US Outer Continental Shelf. Report to the US Bureau of Land Management, Washington DC, Contract no. AA551-CT8-48. 586pp.

Chapman, D.C. and Beardsley, R.C. 1989. On the origin of shelf water in the Middle Atlantic Bight. J. Phys. Oceanogr. 19:384-91.

Chen, C., Beardsley, R.C. and Limeburner, R. 1995a. Variability of currents in late spring in the northern Great South Channel. Cont. Shelf Res. 15:451-73.

Chen, C., Beardsley, R.C. and Limeburner, R. 1995b. Variability of water properties in late spring in the northern Great South Channel. Cont. Shelf Res. 15:415-31.
Comita, G.W., Marshall, S.M. and Orr, A.P. 1966. On the biology of Calanus finnmarchicus; XIII. Seasonal change in weight, calorific value and organic matter. J. Mar. Biol. Assoc. UK 46:1-17.

Crone, M.J. and Kraus, S.D. (eds.). 1990. Right Whales (Eubalaena glacialis), in the Western North Atlantic: A Catalog of Identified Individuals. New England Aquarium, Boston. 223pp.

Curry, R.G. and McCartney, M.S. 1996. Labrador Sea water carries northern climate signal south. Oceanus 39(2):24-8.

Durbin, E.G., Campbell, R.G., Gilman, S.L. and Durbin, A.G. 1995a. Diel feeding behaviour and ingestion rate in the copepod Calanus finmarchicus in the southern Gulf of Maine during late spring. Cont. Shelf Res. 15(4-5):539-70.

Durbin, E.G., Durbin, A.G. and Beardsley, R.C. 1995b. Springtime nutrient and chlorophyll a concentrations in the southwestern Gulf of Maine. Cont. Shelf Res. 15:433-50.

Durbin, E.G., Gilman, S.L., Campbell, R.G. and Durbin, A.G. 1995c. Abundance, biomass, vertical migration and estimated development rate of the copepod Calanus finmarchicus in the southern Gulf of Maine during late spring. Cont. Shelf Res. 15(4-5):571-91.

Dutton, E.G. and Christy, J.R. 1992. Solar radiative forcing at selected locations and evidence for global lower tropospheric cooling following the eruptions of El Chichón and Pinatubo. Geophys. Res. Lett. 19:2,313-6.

Ford, R.G. 1989. CAMRIS-Computer Aided Mapping and Resource Inventory System. Ecological Consulting, Inc., Portland, OR. 64pp.

Fromentin, J.M. and Planque, B. 1996. Calanus and environment in the eastern North Atlantic. II. Influence of the North Atlantic Oscillation on C. finmarchicus and C. helgolandicus. Mar. Ecol. Prog. Ser. 134:111-8.

Gallager, S.M., Davis, C.S., Epstein, A.W., Solow, A. and Beardsley, R.C. 1996. High-resolution observations of plankton spatial distributions correlated with hydrography in the Great South Channel, Georges Bank. Deep-Sea Res. 43:1,627-63.

Gaskin, D.E. 1982. The Ecology of Whales and Dolphins. Heinemann, London. 459pp.

Gaskin, D.E. 1987. Updated status of the right whale, Eubalaena glacialis, in Canada. Can. Field-Nat. 101(2):295-309.

Gaskin, D.E. 1991. An update on the status of the right whale, Eubalaena glacialis, in Canada. Can. Field-Nat. 105(2): 198-205.

Hamilton, P.K. and Mayo, C.A. 1990. Population characteristics of right whales (Eubalaena glacialis) observed in Cape Cod and Massachusetts Bays, 1978-1986. Rep. int. Whal. Commn (special issue) $12: 203-8$

Han, G. and Tang, C.L. 1999. Velocity and transport of the Labrador Current determined from altimetric, hydrographic, and wind data. J. Geophys. Res. C 104:18,047-57.

Hansen, J., Lacis, A., Ruedy, R. and Sato, M. 1992. Potential climatic impact of Mount Pinatubo eruption. Geophys. Res. Lett. 19:215-18.

Hardy, A.C. 1956. The Open Sea-Its Natural History: The World of Plankton. Collins, London. xiv+335pp.

Hays, G.C., Carr, M.R. and Taylor, A.H. 1993. The relationship between Gulf Stream position and copepod abundance derived from the Continuous Plankton Recorder survey: separating biological signal from sampling noise. J. Plankton Res. 15:1,359-73.

Hentschel, E. 1937. Naturgeschichte de nord-atlantische Wale und Robben. pp. 1-54. In: Lubbert and Ehrenbaum (eds.) Handbuch Seefischerei NordEuropas. Schweizerbart, Stuttgart.

Hjort, J. and Ruud, J.T. 1929. Whaling and fishing in the North Atlantic. Rapp. P-V Réun. Cons. Int. Explor. Mer 56:5-123.

Hurrell, J.W. 1995. Decadal trends in the North Atlantic Oscillation: regional temperatures and precipitations. Science 269:676-9.

International Whaling Commission. 1986. Report of the Workshop on the Status of Right Whales. Rep. int. Whal. Commn (special issue) 10:1-33.

International Whaling Commission. 2001a. Report of the Workshop on Status and Trends of Western North Atlantic Right Whales. J. Cetacean Res. Manage. (special issue) 2:61-87.

International Whaling Commission. 2001b. Report of the Workshop on the Comprehensive Assessment of Right Whales: A worldwide comparison. J. Cetacean Res. Manage. (special issue) 2:1-60.

Jones, P.D. and Kelly, P.M. 1996. The effects of tropical explosive volcanic eruptions on surface air temperature. pp. 95-111. In: G Fiocco, D. Fuà and G. Visconti (eds.) The Mount Pinatubo Eruption: Effects on the Atmosphere and Climate. Springer-Verlag, Berlin. NATO ASI Series I, Global Environmental Change, vol. 42. pp.viii+310pp.

Katona, S. and Whitehead, H. 1988. Are Cetacea ecologically important? Oceanogr. Mar. Biol. Ann. Rev. 26:553-68. 
Keller, M.D. 1991. Dimethyl sulfide production and marine phytoplankton: the importance of species composition. Biol. Oceanogr. 6:375-82.

Kenney, R.D. 1994. Anomalous 1992 Spring and Summer Distributions of Right Whales (Eubalaena glacialis) and other Cetaceans in Continental Shelf Waters Off the Northeastern United States and Adjacent Canada. Final Report to US Marine Mammal Commission, Washington, DC, Contract No. T94070648. $65 \mathrm{pp}$.

Kenney, R.D. and Winn, H.E. 1986a. Aerial surveys of right whales in the Great South Channel, spring 1986. Final Report, order no. 12504, to Minerals Management Service, Washington, DC. 13pp. (unpublished).

Kenney, R.D. and Winn, H.E. 1986b. Cetacean high-use habitats of the northeast US continental shelf. Fish. Bull. 84:345-57.

Kenney, R.D. and Winn, H.E. 1987. Aerial surveys of right whales in the Great South Channel, spring 1987. Final Report, order no. 14624, to Minerals Management Service, Washington, DC. 30pp. (unpublished).

Kenney, R.D. and Wishner, K.F. 1995. The South Channel Ocean Productivity EXperiment. Cont. Shelf Res. 15(4-5):373-84.

Kenney, R.D., Hyman, M.A.M., Owen, R.E., Scott, G.P. and Winn, H.E. 1986a. Estimation of prey densities required by western North Atlantic right whales. Mar. Mammal Sci. 2(1):1-13.

Kenney, R.D., Winn, H.E. and Brown, C.W. 1986b. Aerial surveys for right whales in the Great South Channel, Spring 1985. Final Report to NMFS, Northeast Fisheries Center, Woods Hole, MA, Contract No. NA-84-EA-C-00079. 48pp. (unpublished).

Kenney, R.D., Winn, H.E. and Macaulay, M.C. 1995. Cetaceans in the Great South Channel, 1979-1989: Right whale (Eubalaena glacialis). Cont. Shelf Res. 15(4-5):385-414.

Kerr, R.A. 1993. Pinatubo global cooling on target. Science 259:594.

Khatiwala, S.P. and Fairbanks, R.G. 1999. Freshwater sources to the coastal oceans of northeastern North America: Evidence from $\mathrm{H}_{2}{ }^{18} \mathrm{O} / \mathrm{H}_{2}{ }^{16} \mathrm{O}$. J. Geophys. Res. C 104:18,241-255.

Knowlton, A.R., Sigurjónsson, J., Ciano, J.N. and Kraus, S.D. 1992. Long-distance movements of North Atlantic right whales (Eubalaena glacialis). Mar. Mammal Sci. 8(4):397-405.

Kraus, S.D. 1985. A review of the status of right whales (Eubalaena glacialis) in the western North Atlantic with a summary of research and management needs. Final Report to the US Marine Mammal Commission, NTIS no. PB86154143, Washington, DC. 61pp.

Kraus, S.D. and Kenney, R.D. 1991. Information on right whales (Eubalaena glacialis) in three proposed critical habitats in United States waters of the western North Atlantic Ocean. Report to Marine Mammal Commission, Washington, DC, Contract Nos T-75133740 and T-75133753. 65pp.

Kraus, S.D., Moore, K.E., Price, C.A., Crone, M.J., Watkins, W.A., Winn, H.E. and Prescott, J.H. 1986. The use of photographs to identify individual North Atlantic right whales (Eubalaena glacialis). Rep. int. Whal. Commn (special issue) 10:145-51.

Kraus, S.D., Crone, M.J. and Knowlton, A.R. 1988. The North Atlantic right whale. pp. 684-98. In: W.J. Chandler (ed.) Audubon Wildlife Report 1988/1989. Academic Press, New York. 817pp.

Lalli, C.M. and Gilmer, R.W. 1989. Pelagic Snails-The Biology of Holoplanktonic Gastropod Molluscs. Stanford University Press, Stanford, CA. xiv+259pp.

Lawrence, G.C. 1976. Caloric values of some North Atlantic calanoid copepods. Fish. Bull. 74:218-0.

Liss, P.S., Malin, G., Turner, S.M. and Holligen, P.M. 1994. Dimethyl sulfide and Phaeocystis: a review. J. Mar. Systems 5:41-53.

Lowry, L. 1993. Foods and feeding ecology. pp. 201-38. In: J.J. Burns, J.J. Montague and C.J. Cowles (eds.) Special Publication. No. 2. The Bowhead Whale. 1st. Edn. Society for Marine Mammalogy, Lawrence, Kansas. xxxvi+787pp.

Lowry, L.F. and Frost, K.J. 1984. Foods and feeding of bowhead whales in western and northern Alaska. Sci. Rep. Whales Res. Inst., Tokyo 35:1-16.

Luhr, J.F. 1991. Volcanic shade causes cooling. Nature, Lond. 354:104-5.

Macaulay, M.C., Wishner, K.F. and Daly, K.L. 1995. Acoustic scattering from zooplankton and micronekton in relation to a whale feeding site near Georges Bank and Cape Cod. Cont. Shelf Res. 15(4-5):509-37.

MacGinitie, G.E. 1955. Distribution and ecology of marine invertebrates of Point Barrow, Alaska. Smithson. Misc. Collect. 128(9):1-201.

Marquette, W.M. 1978. Bowhead whale. pp. 70-81. In: D. Haley (ed.) Marine Mammals of Eastern North Pacific and Arctic Waters. Pacific Search Press, Seattle, Washington. 256pp.
Marshall, S.M. and Orr, A.P. 1972. The Biology of a Marine Copepod. Springer-Verlag, New York. vii+195pp.

Matthews, L.H. 1938. Notes on the southern right whale, Eubalaena australis. Discovery Rep. 17:169-82.

Mayo, C.A. 1982. Observations of cetaceans: Cape Cod Bay and Stellwagen Bank Massachusetts 1975-1979. Final Report to the Marine Mammal Commission, NTIS PB82-186263. 68pp.

Mayo, C.A. and Goldman, L. 1992. Right whale foraging and the plankton resources in Cape Cod and Massachusetts Bays. pp. 43-4. In: J. Hain (ed.) The Right Whale in the Western North Atlantic: A Science and Management Workshop. NEFSC Ref. Doc. 92-05. NMFS, NEFSC, Conservation and Utilization Division, Woods Hole, MA. ix+88pp.

Mayo, C.A. and Marx, M.K. 1990. Surface foraging behaviour of the North Atlantic right whale, Eubalaena glacialis, and associated zooplankton characteristics. Can. J. Zool. 68:2,214-0.

Mayo, C.A., Mattila, D.K., Pittman, S. and Baraff, L.S. 1988. Abundance, distribution and habitat use of large whales in the southern Gulf of Maine. Final Report to the National Marine Fisheries Service, Northeast Fisheries Science Center contract 50-EANF-5-00130. NMFS, NEFSC, Woods Hole, MA 02543. 178pp. (unpublished).

McConnaughey, B.H. 1978. Introduction to Marine Biology. Third Edn. C.V. Mosby, St. Louis, MO. x+624pp.

McCormack, M.P., Thomason, L.W. and Trepte, C.R. 1995. Atmospheric effects of the Mt Pinatubo eruption. Nature, Lond. 373:399-404.

Meise, C.J. and O'Reilly, J.E. 1996. Spatial and seasonal patterns in abundance and age-composition of Calanus finmarchicus in the Gulf of Maine and on Georges Bank. Deep-Sea Res. 43:1,473-501.

Millais, J.G. 1906. The Mammals of Great Britain and Ireland, Vol. 3, Cetacea. Longmans Green, London. xii+384pp.

Miller, C.B., Lynch, D.R., Carlotti, F., Gentleman, W. and Lewis, C.V.W. 1998. Coupling of an individual-based population dynamic model of Calanus finmarchicus to a circulation model for the Georges bank region. Fish Oceanogr. 7:219-34.

Mitchell, E.D., Kozicki, V.M. and Reeves, R.R. 1986. Sightings of right whales, Eubalaena glacialis, on the Scotian Shelf, 1966-1972. Rep. int. Whal. Commn (special issue) 10:83-107.

Murison, L.D. and Gaskin, D.E. 1989. The distribution of right whales and zooplankton in the Bay of Fundy, Canada. Can. J. Zool. 67(6):1,411-20.

National Marine Fisheries Service. 1991. Recovery plan for the northern right whale, Eubalaena glacialis. Prepared by the Right Whale Recovery Team for the NMFS, 1335 East-West Highway, Silver Spring, MD 20910, USA. vi+86pp.

Omura, H., Ohsumi, S., Nemoto, R., Nasu, K. and Kasuya, T. 1969. Black right whales in the North Pacific. Sci. Rep. Whales Res. Inst., Tokyo 21:1-78.

Payne, P.M., Wiley, D.N., Young, S.B., Pittman, S., Clapham, P.J. and Jossi, J.W. 1990. Recent fluctuations in the abundance of baleen whales in the southern Gulf of Maine in relation to changes in selected prey. Fish. Bull. 88:687-96.

Percy, J.A. and Fife, F.J. 1981. The biochemical composition and energy content of Arctic marine macrozooplankton. Arctic 34:307-17.

Petrie, B. and Drinkwater, K. 1993. Temperature and salinity variability on the Scotian Shelf and in the Gulf of Maine 1945-1990. J. Geophys. Res. 98:20,079-89.

Pratt, H.S. 1935. A Manual of the Common Invertebrate Animals (Exclusive of Insects). P. Blakiston's Son \& Co., Philadelphia. xviii+854pp.

Read, J.F. and Gould, W.J. 1992. Cooling and freshening of the subpolar North Atlantic Ocean since the 1960s. Nature, Lond. 360:55-7.

Reid, P.C., Planque, B. and Edwards, M. 1998. Is observed variability in the long-term results of the Continuous Plankton Recorder survey a response to climate change? Fish Oceanogr. 7:282-8.

Scott, G.P. and Gilbert, J.R. 1982. Problems and progress in the US BLM-sponsored CETAP surveys. Rep. int. Whal. Commn 32:587-600.

Scott, G.P., Kenney, R.D., Owen, R.E., Hyman, M.A.M. and Winn, H.E. 1985. Biological and physical oceanographic correlatives to cetacean density distribution in the Great South Channel. Paper CM 1985/N:/REF L presented to ICES, Biological Oceanography Committee of Marine Mammal Committee. 18pp. (unpublished).

Sherman, K., Smith, W.G., Green, J.R., Cohen, E.B., Berman, M.S., Marti, K.A. and Goulet, J.R. 1987. Zooplankton production and the fisheries of the northeastern shelf. pp. 268-82. In: R.H. Backus and 
D.W. Bourne (eds.) Georges Bank. MIT Press, Cambridge, MA. $\mathrm{x}+593 \mathrm{pp}$.

Shoop, C.R. and Kenney, R.D. 1992. Seasonal distributions and abundances of loggerhead and leatherback sea turtles in waters of the northeastern United States. Herpetol. Monogr. 6:43-67.

Shuman, C.A., Fahnstock, M.A., Bindschadler, R.A., Alley, R.B. and Stearns, C.R. 1996. Composite temperature record from the Greenland Summit, 1987-1994: synthesis of multiple automatic weather station records and SSM/I Brightness temperatures. Journal of Climate 9:1,421-8.

Slijper, E.J. 1962. Whales. 1st English Edn. Hutchinson \& Co., London. 475pp. [Translation of the Dutch book Walvissen published in 1958].

Sverdrup, H.U., Johnson, M.W. and Fleming, R.H. 1942. The Oceans. Their Physics, Chemistry, and General Biology. Prentice-Hall, Inc., New York. $\mathrm{x}+1,087 \mathrm{pp}$.

Taylor, A.H. 1995. North-south shifts of the Gulf Stream and their climatic connection with the abundance of zooplankton in the UK and surrounding areas. ICES J. Mar. Sci. 52:711-21.

Taylor, A.H. 1996. North-south shifts of the Gulf Stream: ocean-atmosphere interactions in the North Atlantic. Int. J. Climatol. 16:559-83.

Taylor, A.H., Colebrook, J.M., Stephens, J.A. and Baker, N.G. 1992. Latitudinal displacements of the Gulf Stream and the abundance of plankton in the north-east Atlantic. J. Mar. Biol. Assoc. UK 72:919-21.

Taylor, A.H., Jordan, M.B. and Stephens, J.A. 1998. Gulf Stream shifts following ENSO events. Nature, Lond. 393:638.

Tomilin, A.G. 1957. Zveri SSSR i Prilezhasfchikh Stran. Zveri Vostochnoi Evropy i Severnoi Azii. Izdatel'stvo Akademi Nauk SSSR, Moscow. 756pp. [Translated in 1967 as Mammals of the USSR and Adjacent Countries. Mammals of Eastern Europe and Adjacent Countries. Vol. IX. Cetacea by the Israel Program for Scientific Translations, Jerusalem, 717pp.][In Russian].

Townsend, D.W. 1992. An overview of the oceanography and biological productivity of the Gulf of Maine. pp. 5-26. In: D.W.
Townsend and P.F. Larsen (eds.) Gulf of Maine. NOAA Coastal Ocean Program Regional Synthesis Series Number 1. NOAA Coastal Program Office, Washington, DC. iv+135pp.

van Loon, H. and Rogers, J.C. 1978. The seesaw in winter temperatures between Greenland and northern Europe. Part I: General description. Monthly Weather Rev. 106:296-310.

Watkins, W.A. and Schevill, W.E. 1976. Right whale feeding and baleen rattle. J. Mammal. 57(1):58-66.

Watkins, W.A. and Schevill, W.E. 1979. Aerial observations of feeding behavior in four baleen whales, Eubalaena glacialis, Balaenoptera borealis, Megaptera novaeangliae and Balaenoptera physalus. J. Mammal. 60(1):155-63.

Williams, R. and Lindley, J.A. 1980. Plankton of the Fladen Ground during Flex 76. III. Vertical distribution, population dynamics and production of Calanus finmarchicus (Crustacea: Copepoda). Mar. Biol. 60:47-56.

Wimpenny, R.S. 1966. The Plankton of the Sea. American Elsevier Publishing Co., New York. 426pp.

Winn, H.E., Scott, E.A. and Kenney, R.D. 1985. Aerial Surveys for Right Whales in the Great South Channel, Spring 1984. Report to Marine Mammal Commission, Washington, DC, No. MMC-84/04. 18 pp.

Winn, H.E., Price, C.A. and Sorensen, P.W. 1986. The distributional biology of the right whale (Eubalaena glacialis) in the western North Atlantic. Rep. int. Whal. Commn (special issue) 10:129-38.

Wishner, K., Durbin, E., Durbin, A., Macaulay, M., Winn, H. and Kenney, R. 1988. Copepod patches and right whales in the Great South Channel off New England. Bull. Mar. Sci. 43(3):825-44.

Wishner, K.F., Schoenherr, J.R., Beardsley, R. and Chen, C.S. 1995. Abundance, distribution and population structure of the copepod Calanus finmarchicus in a springtime right whale feeding area in the southwestern Gulf of Maine. Cont. Shelf Res. 15(4-5):475-507. 